\title{
Lingvistik, dialogism, hermeneutik Om språkvetenskapens kunskapsobjekt
}

Die Hermeneutik und Grammatik müssen zuzammen bearbeitet werden.

(Friedrich Schlegel, Zur Philologie. II, 1797)

\begin{abstract}
Andreas Widoff
En stor del av språkvetenskapen vilar sedan länge på en snäv idé om sitt kunskapsobjekt. Inställningen är nomotetisk och logocentrisk. Med språk avses ett regelbundet system. Fastän denna inställning mött mycket motstånd, har den väl i praktiken aldrig skakats $\mathrm{i}$ grunden. Denna undersökning försöker därför ännu en gång att presentera ett alternativt språkbegrepp. Teorin är dialogisk och hermeneutisk: den språkliga betydelsens plats i världen och tolkningen som grunden för all betydelse är vägledande principer. Genom dessa principer introduceras två begreppsliga ramverk. Det första lägger grunden för en kontinuerlig språkmodell som försöker att upplösa dikotomin mellan system och bruk. Till denna modell fogas sedan en tolkningstypologi. Denna har ett dubbelt syfte. Å ena sidan möjliggör den en systematisk jämförelse av språkvetenskapens discipliner. Å andra sidan är den en beskrivning av språkets betydelsestruktur.
\end{abstract}

Språkvetenskapens kunskapsobjekt är inte givet. För att inse detta räcker det att beakta all den forskning som samsas under benämningen. Däremot är kunskapsobjektet ofta självklart inom vissa av dess discipliner. Ibland förefaller det teoretiskt definierat och motiverat, andra gånger snarare utkristalliserat genom praktiken. Men vad det gäller att inse är att språket som kunskapsobjekt konsolideras genom såväl teori som praktik. Innan vi ger oss in i språkstudiet har vi oundvikligen gjort oss en föreställning om vad språket är, och med denna föreställning följer en särskild blick i forskningens praktik. Genom studiet lär vi oss sedan på erfarenhetens grund att språket är vad vi ser, och denna er- 


\section{Andreas Widoff}

farenhet lägger grunden för teorin. Vad vi skaffar oss kunskap om är tätt sammanflätat med hur vi skaffar oss denna kunskap. Disciplinen befinner sig således i en spiral av självbekräftelse, även om givetvis motsättningar mellan teori och erfarenhet kan uppstå, som leder till en omkullkastning av dess premisser. Detta förhållande är oundvikligt och inte en kritik av språkvetenskapen i sig. Men det manar till några klargöranden. På vilken grundval står i själva verket språkforskningen? Hur bildas dess kunskapsobjekt? Vad är det en språkvetare egentligen vet?

Dessa frågor låter sig inte besvaras i en handvändning. De kräver åtskilliga överväganden, och eftersom dessa är en reaktion på tidigare överväganden, låter de sig inte heller gärna göras ute i tomma luften. Nyanserna träder fram först mot bakgrunden. Innan jag närmare presenterar mina förslag ska jag därför ta avstamp i vetenskapshistorien. Först bekantar vi oss kort med Saussure, Hjelmslev, Chomsky, Austin och Searle. Sedan övergår jag till Bachtin, Volosjinov, Heidegger och Gadamer. ${ }^{1}$ Det ska redan nu sägas att mitt exegetiska intresse för dessa senare författarskap är litet; vad det här handlar om är att finna fruktbara ingångar för språkvetenskapen. Undersökningen avslutas med en tolkningstypologi som dels utvecklar begreppet om språklig betydelse, dels möjliggör en systematisk jämförelse mellan olika sätt att bedriva forskning inom såväl språkvetenskapen som andra humanvetenskapliga fält.

Det mest bekanta exemplet på en omsorgsfullt genomförd deklaration av språkvetenskapens kunskapsobjekt återfinns i Saussures begreppspar la langue och la parole ([1916] 1970:29-44). La parole, som är den exekutiva sidan av kommunikationen, själva talandet, betraktar han som individuellt, underordnat och mer eller mindre tillfälligt. La langue däremot är ett väldefinierat objekt inom den oordnade massan av fakta. La langue är alltså homogent och la parole heterogent. En snarlik distinktion återkommer senare hos Hjelmslev under begreppsparen system-forlфb och sprog-text (1943:16 och 36). Här saknar dock systembegreppet Saussures ontologiska anspråk, för Hjelmslev handlar det om metodologi. Ännu något senare inför Chomsky (1965:4) en mer subjektivistisk distinktion mellan competence och performance. Tanken är att talare producerar yttranden som i själva verket inte motsvarar deras inre grammatik. Sådana fakta behöver språkforskaren enligt Chomsky inte ta hänsyn till. På samma sätt behandlar lingvistiken enligt Saussure uteslutande la langue; alla de heterogena fakta som hör till la parole ligger utanför dess område. Även inom pragmatiken återfinns 


\section{Lingvistik, dialogism, hermeneutik}

samma tankegång. Austin (1962) ägnar visserligen möda åt att beskriva de infelicities som kan drabba performativa yttranden, men synbarligen endast med syftet att dra en skarp gräns mellan de som är happy och de som är unhappy. Villkoren som bifaller de förra är det väsentliga. Searle (1969) säger i princip samma sak med termerna non-defective och defective (s. 54). Han understryker dessutom att studiet av språkhandlingar rör la langue, inte la parole (s. 17). Kunskapsobjektet konstrueras alltså i alla dessa fall genom att vissa fakta avvisas som irrelevanta. Vilka förutsättningar skapar egentligen ett sådant kunskapsobjekt för den vetenskapliga praktiken?

Innan vetenskapen om la langue, den allmänna lingvistiken såsom Saussure föreställer sig den, ens är etablerad postulerar han att dess ämne är "väl avgränsat” [bien défini] (1970:38). Det är nog inte för mycket att här tala om en självuppfyllande förutsägelse. Med denna premiss är det givet att strukturell enhet kommer att föredras på bekostnad av faktarikedomen. Många mänskliga fakta som åtföljer språket har ingen plats i systemet. Allt vad människan erfar, allt vad hon tänker, känner och förnimmer som gensvar på språkliga tecken, reduceras till formella kategorier. Dessa ofta mångtydiga fenomen skjuts helt enkelt åt sidan för det jämförelsevis entydiga språksystemet. Av denna anledning uppfattas ofta tolkning som främmande för lingvistiken. Den antas syssla med objektiva och konkreta fakta. ${ }^{2}$

Den här karaktäristiken tror jag inte endast är giltig för Saussure, utan träffande för den moderna lingvistiken överhuvud. Om vi anlitar Ludwik Fleck (1997), den polske biologen och vetenskapsteoretikern, kan vi säga att den moderna lingvistiken består av ett tankekollektiv som kännetecknas av en viss tankestil. Inom ett sådant kollektiv kan många skilda och stridande skolor rymmas. De elementära vetenskapliga premisserna kan trots detta vara desamma.

En av den moderna lingvistikens premisser är dess naturvetenskapliga vetenskapsideal. Tankestilen är logocentrisk och nomotetisk och föredrar erklären framför verstehen. Den är också mån om att framhålla språkvetenskapen som en unik vetenskap, vilken har sitt speciella kunskapsobjekt som inte delas med några andra vetenskaper. Dessa karaktäristika är dock alltför generella för att ringa in endast den moderna lingvistiken. Till dess mer specifika kännetecken hör dikotomin mellan ett regelbundet system och ett mindre regelbundet bruk, en påtaglig ovilja att studera detta bruk, och en abstrakt föreställning om betydelser. Det sista kännetecknet är nog tankestilens fundamentala princip. De två 


\section{Andreas Widoff}

grammatiska enheterna fonemet och morfemet är bra exempel på detta. Enligt de gängse definitionerna är fonemet språkets minsta betydelseskiljande enhet och morfemet språkets minsta betydelsebärande enhet. När dessa enheter introducerades var det givetvis ett stort framsteg för grammatiken. Men just endast så: för grammatiken. Om vi lämnar den abstrakta föreställningen om betydelser behöver vi inte vistas länge $i$ världen för att märka att vissa allofoner är socialt utskiljande och därmed språkliga bärare av mening (jfr Gregersen 2006:45f). Definitionerna av fonemet och morfemet är således giltiga endast så länge vi upprätthåller ett visst perspektiv på betydelser. Det är som redan Saussure påpekade om lingvistiken: "Långtifrån att föremålet föregår studiet skulle man hellre säga, att det är betraktelsesättet som skapar föremålet” (1970:31). Den allmänna acceptansen av dessa två definitioner torde påvisa den abstrakta betydelsens fundamentala status i den moderna lingvistiska tankestilen.

Ungefär så kan den dominerande språkvetenskapliga tendensen beskrivas. I ett nordiskt land korsas förstås denna tendens med den inhemska traditionen, nordistiken, som har sin egen prägel och fasta tradition. Även om det vore intressant, finns inte utrymme att diskutera denna närmare här. Se istället Henriksen et al. (1996) och Hovdhaugen et al. (2000)

Internationellt finns vid sidan av den moderna lingvistiken många andra tendenser. En del av dessa föreslår, liksom jag i denna artikel, en mindre formalistisk orientering inom språkforskningen. En av dessa tendenser utgörs av den systemisk-funktionella lingvistiken (t.ex. Halliday 2004). En annan av sociosemiotiken, vilken är nära förbunden med den förra (t.ex. Halliday 1978 och Hodge \& Kress 1988). En tredje av kritisk diskursanalys (t.ex. Fairclough 1992). En fjärde av polyfon lingvistik (t.ex. Therkelsen et al. 2007). En femte av interaktionell lingvistik (t.ex. Linell 1998). Osv. Det är inte dessa tendenser jag har för avsikt att framhålla här. Det är självklart orättvist att avfärda dem alla i en handvändning - var och en har sina företräden - men jag ska ändå förklara min drivkraft. Att systemisk-funktionell grammatik och sociosemiotik har rötter i strukturalismen är ingen hemlighet. I vilken mån dessa skiljer sig från den moderna lingvistiken kan diskuteras. Detta gäller väl inte för den kritiska diskursanalysen, även om ett strukturalistiskt arv skymtar också här. Interaktionell och polyfon lingvistik, slutligen, är förvisso representanter för dialogismen, men de ägnar frågan om tolkning liten uppmärksamhet. De tre första tendenserna är alltså måttligt dialogiska, och ingen av tendenserna är hermeneutisk. Gen- 
temot dessa föreslår jag en förening av två perspektiv: en bachtinsk dialogism med en fenomenologisk hermeneutik. Som samlingsnamn på det hela talar jag om en dialogisk språkvetenskap. "Dialog" ska då förstås i sin vidaste mening, som en term besläktad med "dialektik". Den behåller dock, till skillnad från den samtida förståelsen av dialektik, en innebörd av samtal.

Medan hermeneutiken i våra dagar sällan är på tal inom språkvetenskapen, kan inte detsamma sägas om Bachtin. Men med undantag för några fästen för den polyfona lingvistiken har såvitt jag sett ett genuint intresse saknats. Bachtin nämns inte sällan som referens. Det rör sig emellertid knappast om någon välrotad teori. Läsningen sträcker sig till ett fåtal verk - sällan längre än till Frågan om talgenrer och Ordet $i$ romanen - och referaten av idéerna är relativt ytliga. Bachtinförståelsen kan nog sammanfattas i utsagorna "Texter är avsedda för respons", “Texter är riktade" och "Texter hänvisar till andra texter", vilka motsvarar begreppen finalitet, adressivitet och intertextualitet. Dessa utsagor är nog så viktiga, men inte tillräckliga för en dialogisk teori. I det följande hamnar de därför i bakgrunden, medan andra, i min mening mer fundamentala idéer träder fram.

Härvid fäster jag en del avseende vid Volosjinov. Detta är inte utan konsekvenser. Trots allt som sagts om förhållandet mellan Bachtin och Volosjinov är deras metoder inte alldeles lika. Volosjinov framstår som en föredömlig marxist med dialektiken i högsta hugg, Bachtin som en fri filosof som inte låter sig ledas i uppgångna tankespår. Volosjinov söker synteser. Hos honom är tänkandet identiteten av identitet och icke-identitet. För Bachtin finns däremot bara motsatta sidor. Tänkandet erbjuder ingen förlikning. Sådan är den principiella skillnaden mellan Bachtins dialog och Volosjinovs dialektik. I det följande ansluter jag mer till Volosjinovs metod, också när jag läser Bachtin.

\section{Dialogism och monologism}

I en schematisk uppställning har Linell (2002) tecknat bilden av västerlandets idéhistoria i termer av två traditioner: den monologiska gentemot den dialogiska. I sin enkelhet har Linells skiss en klar dragningskraft, även om den behöver underbyggas av en idéhistorisk utläggning. Det väsentliga är hur som helst den återkommande motsättningen mellan individualism, rationalism och universalism å ena sidan och historism, konstruktivism och icke-reduktionism å den andra. Den dialogiska språkvetenskap Linell förordar ställer sig på den sistnämnda sidan. 
Idén om en liknande motsättning möter även i Bachtins texter. Efter Morson \& Emersons (1990) förslag kan den dock uttryckas betydligt mer distinkt: ordning kontra oordning. För Bachtin innebär detta att ordning är undantaget. Oordning däremot är sakernas allmänna tillstånd. Nu ska inte detta förstås som en bekännelse till kaos. Bachtins problemställning är snarare att världen förvisso måste vara ordnad för att inte vara fullkomligt slumpartad (dvs. meningslös) men samtidigt oordnad för att tillåta frihet och kreativitet. Det är nämligen det sistnämnda som skapar moment av meningsfull oförutsägbarhet i världen. ${ }^{3}$ Bachtin söker en förståelse som, utan att hamna i en nihilistisk relativism, kan göra reda för världens öppenhet. När han förklarar innebörden av en dostojevskjisk i motsats till en aristotelisk katharsis, uttrycker han samtidigt sin egen allmänna idé: "ingenting slutgiltigt har ännu inträffat $i$ världen, det sista ordet av världen och om världen har ännu inte uttalats, världen är öppen och fri, allt ligger ännu i framtiden och kommer alltid att ligga i framtiden" (1991:177, originalets kursiv). En sådan förståelse måste avvisa en värld reglerad av lagar, eftersom framtiden då redan vore bestämd, men den måste också, om öppenheten ska förbli meningsfull och kreativ, avvisa idén om slumpens verk. Det senare uttrycks i den romantiska tanke som placerar skapelseakten i en avlägsen sfär, i ett mystiskt genius, bortom människans kontroll. Problemet kvarstår även vid mer voluntaristiska uppfattningar. För om skapelseakten antas härröra från ett självständigt subjekt med full kontroll över sin verksamhet, får man - givet mångfalden av sådana subjekt - svårt att förklara världens regelbundenhet. Inom språkvetenskapen tar sig den här motsättningen uttryck i två tankemässiga traditioner. Dessa har beskrivits av Volosjinov (1973 och 1983a) och av honom benämnts individualistisk subjektivism och abstrakt objektivism.

Det är romantiken som historiskt ger näring åt den individualistiska subjektivismen. Volosjinov uppfattar så också Wilhelm von Humboldt som dess främste representant. ${ }^{4}$ I Johann Georg Hamann och Johann Gottfried von Herder, två exponenter för Sturm und Drang, ser han dennes föregångare, och till efterföljarna räknar han romantiska idealister som Heymann Steinthal, Benedetto Croce och Karl Vossler. Subjektivismen kännetecknas av att uppmärksamheten riktas mot den individuella språkförmågan. Detta kommer till klarast uttryck i Humboldts iakttagelse vilken oerhörd kreativ förmåga språkbrukarna besitter, att de "von endlichen Mitteln einen unendlichen Gebrauch machen" - i dag mer känd i Chomskys tappning att språket "makes infinite use of finite means" ([1836] 2003:357 och 1965 s. v). Iakttagelsen sätter 


\section{Lingvistik, dialogism, hermeneutik}

naturligtvis fingret på något väsentligt, men själva utsagan dignar under tyngden av ordet "oändligt". Förmågan och kreationen är praktiskt taget begränsade av såväl kognitiva som sociala skäl. Det räcker att påpeka hur svårt det kan vara att klä nya tankar i ord och hur starkt sammanhangen begränsar vårt språk. Detta "praktiskt taget" måste utläsas "i realiteten". Men subjektivismen är idealistisk och tänker sig språket som virtuell maskin. Eftersom den placerar den produktiva instansens oändlighet i det isolerade subjektets förmåga, blir det svårt att föreställa sig omgivningen som något annat än ett hinder, som inskränkningen av subjektets oerhörda möjlighet.

Den abstrakta objektivismens självklara stjärna är Saussure. Även om också Saussure ser la langue som ett psykologiskt fenomen har denna entitet hos honom en social och objektiv karaktär. Det handlar inte så mycket om den individuella förmågan som om konventionernas tvång. Saussures hållning är som vi sett mycket bestämd: den faktiska händelsen intresserar honom endast i egenskap av lagmässig instansering. Det som inte hör hit lämnar han som en formlöst rest utanför den lingvistiska beskrivningen. Denna rest är emellertid inte den lilla återstoden efter en stor operation, utan den stora massan som utstår den lilla operationens stick. Objektivismens synfält är alltså mycket snävt. Detta blir ett problem då den uppfattar systemet som språkets väsen, vars absoluta skillnad till andra fenomen måste upprätthållas. ${ }^{5}$

Saussures hållning är visserligen extrem. Den moderna lingvistiken hanterar sedan länge förhållandet mellan la langue och la parole på mer nyanserade sätt. Denna mjukare uppdelning kan vi benämna system-bruk. Skillnaden består i att bruket till skillnad från la parole antas ingå i den vetenskapliga beskrivningen. Men även här uppstår problem, eftersom tankegången som kondenserat uttrycks i frasen att bruka systemet sammanför två motstridiga perspektiv. Från min synpunkt är en sådan fras lika omöjlig som att dricka sten. Detta måste förklaras i anslutning till tre olika (men ofta samtidiga) förståelser av relationen mellan system och bruk. Den första förståelsen relaterar det regelbundna till det oregelbundna. Systemet är vad man kan förutsäga. Bruket är allt det oväntade. När någon oväntad betydelse av en sträng tecken aktualiseras har det alltså med bruket att göra. Men för att kommunikationen ska fungera behövs inte endast välordnade grammatikor, utan också regelbundenhet i vårt sätt att faktiskt tala med varandra. Bruket kan alltså inte vara oregelbundet. Dessutom har samtalsforskningens landvinningar givit mer än nog evidens mot en sådan uppfattning. Om man mot denna karaktäristik vill kontra med att mjuka upp gränserna, 
genom att räkna med det mer eller mindre regelbundna, snarare än med det fullt eller inte alls regelbundna, så får man svårt att motivera den starka skiljelinjen mellan de två begreppen. System och bruk kunde lika gärna ses som en kontinuerlig helhet. Den andra förståelsen relaterar det objektiva till det subjektiva. Avvikelser från systemet förklaras som subjektiva överträdelser. Detta är vad som ibland kallas Humpty Dumpty-betydelse: "“When I use a word,' Humpty Dumpty said, in a rather scornful tone, 'it means just what I choose it to mean - neither more nor less"” (Carroll 1992:163). På detta sätt kan nya metaforer och poesi förklaras. Problemet är att sådana överträdelser förekommer hela tiden och är en inneboende del av språkets sätt att fungera. Annars skulle språket vara obrukbart. Strikt taget: varje gång någon använder ett ord betyder det något det aldrig tidigare betytt (se avsnitt 4 nedan). Dessa två förståelser blir sällan explicit formulerade, men de tar sig likväl uttryck i den lingvistiska praktikens konstruktion av sitt kunskapsobjekt, som ju idealt består i allmängiltiga förutsägelser. Den tredje förståelsen är den mest nyanserade och kan sägas sammanfatta de två andra och lägga mer därtill. Den relaterar enkelt uttryckt allmänt till specifikt eller språket över världen till språket $i$ världen. Systemet skapas genom att generalisera från världens mångsidighet till formella kategorier. Men eftersom dessa kategorier inte kan vara förutan världen, utan måste gå tillbaka på den värld som språket fortlever i, kan inte systemet förstås som något annat än ett koncentrat av många instanser av bruk och således essentiellt som bruk. Denna förståelse diskvalificerar således i sig själv tanken om ett autonomt språksystem. Dessa problem kan uppfattas som gränsdragningsproblem eftersom det är så de konkret tar sig uttryck i den vetenskapliga praktiken. Men i grunden är de oförenlighetsproblem som uppenbarar sig om vi fördomsfritt beaktar begreppen: regelbundenhet-oregelbundenhet, objektiv-subjektiv, utanför-inuti. För att lösa detta måste man antingen inta en radikal hållning åt endera hållet eller justera begreppen i en förvisso välmenande eklekticism. Dricka blir lite mer som äta eller sten lite mer som vatten.

Lösningen som infinner sig - det må vara en uttjatad formel är att överge de inadekvata dikotomierna. Därmed behöver vi inte avlägsna skapelseakten från systemet eller systemet från skapelseakten. Som Morson \& Emerson formulerat Bachtins idé: "The only way for creativity to be real is for it to be immanent in constant, ongoing processes" (1990:40). Vi får anledning att återkomma till denna idé i nästa avsnitt. 


\section{Lingvistik, dialogism, hermeneutik}

\section{Det dialogiska yttrandet}

I rubriken ovan är attributet icke-restriktivt. Det är viktigt att säga, för det finns också en annan sorts dialogiskt yttrande - som kännetecknas av den rika dialogiska reflektionen inom yttrandet - där attributet snarare är restriktivt. Enligt den idé som behandlas här är alla yttranden dialogiska. På sätt och vis är detta en trivial iakttagelse. Alla yttranden är omgivna av andra yttranden. De existerar inte i ett vakuum. Men det gäller också att låta den triviala insikten få begreppsligt genomslag. Motvilliga medgivanden är en annan sak än att tillåta några egentliga förändringar av tänkandet.

Som ett minimum kan att yttrandet inte endast behandlas som en produkt av talarens fria vilja. Talarens yttrande måste också ses som en respons på vad som sagts tidigare, samtidigt som det antas föregripa kommande yttranden. Detta synsätt är inte främmande i språkforskningen idag. Så långt undviker vi dock inte subjektivismens och objektivismens problem. Antingen anlägger vi en mellanväg med kontexten som ytterligare en faktor vid sidan av intentionen och systemet. Detta gör teorin så lös att vi fritt kan välja perspektiv efter vad som passar bäst för stunden. Eller så antar vi en annan extrem hållning där intentionerna sopas under mattan och den yttre kontexten ses som allt, såsom ofta sker inom Conversation Analysis. Detta är i mina ögon ett olyckligt återupptagande av behaviorismen.

En starkare men syntetiserande teori är önskvärd. Problemställningen är relativt enkel. $\AA$ ena sidan kan vi inte avvisa den objektivitet vi alla är underkastade. Å andra sidan kan vi inte avvisa den individuella kreativa förmågan. Båda vägarna är kontraintuitiva i meningen att de motsäger vår erfarenhet. Trots att problemställningen är enkel verkar motsättningen i allmänhet svår att överkomma. Här finns dock två idéer till hjälp. Den första är Bachtins lösning problemet. Han tänker sig, som vi sett, att kreativiteten är immanent i världen. Den produktiva instansens flyttas således både ut och in på samma gång: ut från individen till omgivningen, in från omgivningen till individen. Subjekt och objekt smälter samman i en dialogicitet. Den andra idén är att människans medvetande i grunden är socialt därför att det är språkligt. Denna idé kan spåras till såväl Humboldt (2003:310f) som Marx \& Engels (1958:433). Därefter formuleras den av Volosjinov (1973:11). Tankegången kan sammanfattas: medvetandet blir till medvetande först när det fyllts med ett språkligt innehåll, och eftersom detta innehåll endast uppstår i interaktion mellan individuella medvetanden, är även det individuella medvetandets inre förståelse i grunden en social process. 


\section{Andreas Widoff}

Sammanför vi dessa två idéer - den immanenta kreativiteten och det social-språkliga medvetandet - framträder språket som en alltid delad skapelse. Vi talar förvisso från vår mun, men vi talar ett redan talat språk. Så även om vi är åtskilda som individer i fysisk mening, är vi som språkliga varelser ofrånkomligt sammanbundna. Yttrandet existerar därmed mellan oss. Det konstrueras inte blott inifrån, i individens själsliv, utan framförallt utifrån, i den sociala miljö som omger denne individ. "The individual speech act (in the strict sense of the word 'individual') is contradictio in adjecto" (Volosjinov 1973:98).

Under tankegången ovan ser vi hur de ursprungliga kategorierna upplöses. Vi överger motsättningen subjekt-objekt för att istället grundlägga intersubjektiviteten som det för handen givna. Utmed ett liknande tankespår har Holquist jämfört uppkomsten av mening med Einsteins idé om det relativa förhållandet mellan kroppar i rörelse: "Dialogism argues that all meaning is relative in the sense that it comes about only as a result of the relation between two bodies occupying simultaneous but different space, where bodies may be thought of as ranging from the immediacy of our physical bodies, to political bodies and to bodies of ideas in general (ideologies)" (Holquist 2002:21). Ingen mening kan enligt detta synsätt existera för sig själv. En språklig händelse måste därför förstås i relationen mellan sändare och mottagare. Den konstrueras inte individuellt på endera sidan, utan uppkommer i relationen mellan de två. Härmed är naturligtvis inte sagt att händelsens mening är densamma för de två, men endast att det utan denna relation överhuvudtaget inte funnes någon mening att uppfatta. Sålunda är det som med rörelse: den uppstår i relationen mellan två kroppar, men uppfattas genom observationen från en viss position.

I Holquists modell sker givetvis en grov förenkling: kontexten är ofantlig men krymps till två kroppar. Den åtnjuter pedagogisk klarhet på bekostnad av komplexiteten. Detta kan vi nu justera genom att föreställa oss samma relationistiska idé men med tusen och åter tusen kroppar av betydelser - kroppar av människor, föremål och yttranden. I ett sådant sammanhang existerar mening i det verkliga livet. Yttrandet betyder $i$ och genom världen av andra betydelser. Detta är innebörden av att yttrandet är dialogiskt. ${ }^{6}$

\section{Det konkreta yttrandet}

Yttrandet är en historisk enhet i vars form allt språk måste gjutas. På så sätt är yttrandet av en annan art än grammatiska enheter. Det skiljer sig

från satsen och kan inte heller jämställas med språkhandlingen. Dessa 


\section{Lingvistik, dialogism, hermeneutik}

är nämligen abstrakta enheter och som sådana iterativa (upprepningsbara). Yttrandet är däremot konkret och unikt. Eftersom situationen aldrig är densamma, kan ett yttrande aldrig upprepas. Vi kan tänka oss en hälsning mellan två personer. "Hej!” - “Hej!”. Vi har två yttranden med identiskt iterativt innehåll. Men de har inte precis samma innebörd. För det första yttras de av olika personer. För det andra har den ene tagit initiativet, den andre svarat. Men om vi tänker oss samma scenario, en annan dag, på samma plats? Nej, skulle Bachtin (1986) säga, att hälsa på någon en viss dag är inte precis detsamma som att hälsa på samma person en annan dag. Däremellan har alltför mycket hänt.

$\mathrm{Nu}$ är inte min avsikt att docera om elementär filosofi. Poängen är att idén om yttrandet som grundläggande enhet påverkar vad vi betraktar som betydelsefullt i kommunikationen. Volosjinov är här tydlig (1973:68). Det avgörande för en talare är inte vad som alltid är detsamma: det språkliga tecknets självidentitet. Det avgörande är det språkliga tecknets förmåga att anta en ny och unik innebörd för talarens aktuella mål. Ett yttrandes relevans avgörs ju av dess funktion i en given kontext. Och att förstå ett yttrande är att förstå vad det innebär här och nu. Låt mig som en illustration citera Wittgensteins gäckande fråga: "Den som varje dag lovar 'I morgon skall jag besöka dig' - säger han varje dag detsamma, eller varje dag något nytt?” (1992:102). Givet den vaga formuleringen måste svaret vara "både och". Men det relevanta för de inblandade är den unika innebörd som situerar en viss morgondag som gällande för löftet - inte att löftet på sätt och vis betyder detsamma som ett liknande för säg fjorton dagar sen.

Vi har nu flyttat fokus från abstrakta enheter i språksystemet till den konkreta verklighetens innebörd. När man talar om konkreta betydelser på detta sätt, måste man beakta alla meningsfulla fenomen som kan förmedlas i ett språkligt material. Också humor, skönhet och allt värdemässigt är meningsfullt, och i vissa sammanhang rentav avgörande. Allt som kan utläsas i ett yttrande tillhör språket rent konkret.

Härmed har jag också smugit in en ny distinktion: konkret gentemot abstrakt betydelse. Betoningen av det konkreta innebär inte att den grammatiska abstraktionen avvisas i sig. Den annorlunda orienteringen är dock fundamental, vilket framgår i undersökningens fortsättning. Redan nu ska jag ge två exempel där det konkreta synsättet vänder vedertagna föreställningar på ända.

Abstrakt och självidentisk betydelse sägs ofta vara "direkt", medan vad som är konkret och skiftande hänförs till betydelsens "indirekta" moment. Det allmänna antas ligga omedelbart "i” orden, det situations- 


\section{Andreas Widoff}

bundna någonstans "utanför” dem. Men frågan är hur relationen mellan dessa världar av betydelser ursprungligen upprättas, och hur den förra kan komma att beteckna saker i den senare. Om betydelser inte kan uppstå utan världsliga sammanhang - om vilket man lätt kan övertyga sig kan den abstrakta betydelsen inte vara något annat än ett koncentrat av många situationer. Den utbredda föreställningen om direkt och indirekt betydelser skapar en oerhörd klyfta mellan ord och situation. Men vad vi behöver är en dialektisk förståelse. Situationen är inte en egen värld av betydelser som betyder för sig själv vid sidan av yttrandet; den är uppkommen såsom situation-för-yttrandet först genom själva yttrandet. På så vis skapar yttrandet situationen liksom situationen skapar yttrandet. Klyvs dessa aspekter itu, kan ett möte aldrig komma till stånd. Orden betyder på sitt hörn, situationen på ett annat. Härifrån får vi svårt att förklara hur ordens betydelser uppstår från första början.

I den mån man alls gör en åtskillnad mellan direkt och indirekt betydelse, föreslår jag därför att man vänder på begreppen. Vad som är omedelbart är den konkreta betydelsen i situationen. Det är denna betydelse som slår oss som blixten, utan att vi avkrävs vare sig eftertanke eller analys, såsom när vi hör en oemotståndlig vits och skrattar direkt. Den isolerade abstrakta betydelsen, som grammatiken laborerar med, är däremot en avledd produkt som uppstår först i en specialiserad tolkningspraktik. Om någon så är det denna betydelse som är indirekt.

Distinktionen mellan synkroni och diakroni är dessvärre fortfarande tämligen vedertagen. För Saussure är skillnaden solklar. Endast det synkrona systemet kan uppbära betydelser. Med en schackliknelse menar han att språkförändringar är drag från ett meningsfullt tillstånd till ett annat. Hur pjäserna kommit till sina platser är likgiltigt (1970:117). Men så kan Saussure endast resonera därför att han tänker i banor av självidentisk betydelse. Betonar vi däremot tecknets förmåga att anta en unik innebörd för varje situation, framträder diakronin som ett fundamentalt elastiskt moment, utan vilket det språkliga tecknet vore oanvändbart i yttrande efter yttrande, genom talarnas ständigt skiftande syften. Diakroni är vad som skiljer unik från självidentisk betydelse. Härmed är inte sagt att studier av en viss tids språk och studier av språkens historiska förändring är samma sak. Det är bara inte frågan om två väsensskilda principer: språkhistorikern studerar den långtida effekten av något som försiggår i varje enskilt yttrande. Problemet med Saussures synkroni är att den förhindrar forskningen om samtidens språk att vara närsynt såsom den historiska forskningen är långsynt. 
Dessa två exempel torde påvisa vikten av distinktionen mellan abstrakt och konkret. I botten av distinktionen lurar en fundamental frågeställning, som vi stötte på redan i Wittgensteins fråga: "Den som varje dag lovar 'I morgon skall jag besöka dig' - säger han varje dag detsamma, eller varje dag något nytt?". Förra gången svarade jag "både och" - och måste göra så igen. Men hur kan det komma sig? Det kommer förstås an på att "säga" är tvetydigt. Å ena sidan: 'säga här och nu'. Å andra sidan: 'säga i allmänhet'. Utan att explicera dessa samtidiga säganden kan vi inte förklara den språkliga princip som Wittgenstein tycks treva efter: att med det gamla varje gång säga något nytt. ${ }^{7}$

\section{Enheten av abstrakt och konkret betydelse}

Abstrakt betydelse avser alltså iterativa betydelser, medan konkret betydelse avser de partikulära betydelser som uppstår i en särskild situation. Ett abstrakt "Ska jag besöka dig?" kan upprepas i otaliga situationer med bibehållen självidentitet. Ett konkret "Ska jag besöka dig?" förekommer däremot endast en gång. Volosjinov benämner dessa aspekter av betydelse mening och tema, men termerna är tyvärr lätta att sammanblanda med andra begrepp. Fortsättningsvis säger jag istället språkelement och språkinstanser. Som en neutral term utan avseende på distinktionen använder jag språkenheter.

Med denna justering har jag inte bara försökt att finna mer entydiga och behändiga termer. Den är också en distansering från Volosjinovs förståelse av begreppen. Volosjinov gör en poäng av att abstrakta betydelser utgörs av analyserbara delar, medan konkreta betydelser består i yttrandens helhet. Men genom att understryka motsättningen mellan del och helhet, riskerar han att upprätthålla distinktionen mellan system och bruk, eftersom han härmed underordnar begreppen två skilda principer. Tanken härrör möjligen från kännetecknen för de tolkningspraktiker som associeras med de två slagen av betydelse. Grammatiken (som laborerar med abstrakta betydelser) är mycket analytisk, medan den alldagliga förståelsen (som umgås med konkreta betydelser) vanligen greppar yttranden i deras helhet. Men att det konkreta inte kan förstås i sina delar, att det inte kan analyseras, är inte riktigt. Volosjinov tycks förbise skillnaden mellan - i Kosíks terminologi (1979) - det pseudokonkreta och det konkreta. Det vill säga skillnaden mellan en alldaglig förståelse av det konkreta i dess omedelbara framträdelse och en dialektisk metod som reder ut det konkretas struktur. Den konkreta världen är inte oregelbunden eftersom alla abstrakta system, i den mån de är 


\section{Andreas Widoff}

giltiga, existerar i just denna värld. Genom de symmetriska termerna språkelement, språkinstanser och språkenheter vill jag betona enheten mellan abstrakt och konkret, att begreppen hänför sig till samma språkliga helhet.

Volosjinov beskriver relationen mellan betydelsens två aspekter i termer av "the upper, actual limit of linguistic significance" (språkinstanser) och "the lower limit of linguistic significance" (språkelement). Längre än så utvecklar han tyvärr inte relationen. Men en konsekvens av formuleringarna är att varje betydelse kräver två samtidiga men motsatta rörelser. I själva verket är det nog här som det största förklaringsvärdet ligger. Betydelse bildas, enligt detta synsätt, dels genom att fastställas som potential, dels genom att fixeras konkret. I det förstnämnda momentet rör vi oss bort från det konkreta yttrandet genom att identifiera iterativa delar som bär upp en självständig betydelse i kraft av att de kan uppträda i andra yttranden med samma betydelse. I det sistnämnda momentet rör vi oss mot det konkreta yttrandet genom att bygga ut denna potential.

Följden av detta är att all betydelse är cirkulär. Sammanför vi denna tankegång med uppfattningen att betydelse är användning så framgår cirkeln ännu tydligare. Språkelementen å ena sidan är genomsnittet av sina användningar. Språkinstanserna å andra sidan är användningarna. Men dessa användningar är inte fria, genuint skapande prestationer, utan kringskurna av språkelementens ramar. Och dessa ramar fastställs av användningarna. Betydelse uppfattas härigenom som relationen av ömsesidig betingning mellan partikulär och universal.

\section{Förståelse och tolkning ${ }^{8}$}

Diskussionen av betydelse har så här långt möjligen givit uttryck åt föreställningen att betydelser föreligger i yttranden som om de vore konkreta ting. Denna föreställning är emellertid en illusion. För att ett yttrande ska betyda något måste det förstås av någon. Sådant som ingen förstår, kan strikt taget inte betyda något. Dessa enkla utsagor kan förefalla banala. De innefattar ingenting som inte tidigare påpekats $i$ den omfattande litteraturen om mening. Men om vi faktiskt fullföljer dem utan avvägar, bör vi anta en betydelseteori som skiljer sig från den som länge varit förhärskande och ännu är det inom språkvetenskapen.

Vi förstår nu inte ett språkligt material som ett ting, med en struktur utanför människans tillvaro. ${ }^{9}$ Det språkliga materialet betyder såsom det är förstått i den fortlöpande strömmen av förståelser. Det äger ingen annan objektivitet än sin intersubjektivitet. Med dessa formuleringar 


\section{Lingvistik, dialogism, hermeneutik}

öppnar sig frågan om tolkning på ett radikalt annorlunda sätt än med vilken som helst hänvisning till den mänskliga förståelsens brister eller begränsningar. Tolkningen är inte något som påförs språket utifrån. Den befinner sig redan inuti språket. För att klargöra den fulla innebörden av detta begrepp om betydelse ska vi beakta Bachtins och Heideggers ståndpunkter.

Enligt Bachtin (1993) är alla tolkningar skiljaktiga: ett yttrande förstås aldrig på ett och samma sätt. ${ }^{10}$ Inte heller detta är särskilt originellt. Att varje upplevelse är unik tar många som ägnat frågan tankemöda för givet (t.ex. Husserl 2004, Ogden \& Richards 1989, Ingarden 1976). Skillnaden består i att Bachtin ger detta en alldeles särskild tyngd. Han vill att vi besinnar oss på tillvarons ständiga unicitet: att var och en existerar på sin unika plats, med sina unika förutsättningar, genom händelse efter händelse, som var och en endast inträffar en gång. Livet som sådant kan därför aldrig fångas i abstrakta principer. Även tanken lyder under samma villkor: genom sin unika och konkreta position antar varje förståelse en unik och konkret kvalitet. Denna idé kan vara svår för vetenskapen att förlika sig med, eftersom den värnar metoder som reducerar den konkreta tillvarons inverkan på tankeinnehållet, men när vi låter den alldagliga erfarenheten träda i dess ställe, måste vi acceptera att ingenting någonsin blir sig likt.

Idén om den unika förståelsen står i kontrast till den förmodligen ännu förhärskande uppfattningen om kommunikation. Denna explicitgjordes första gången i Shannon \& Weavers [1949] matematiska kommunikationsmodell och togs senare över av bland andra Jakobson (1960). Modellen har visserligen angripits många gånger inom bland annat semiotiken och kommunikationsteorin. Men eftersom den inte var ett innovativt bidrag, utan snarare en formulering av en gammal föreställning (som visade sig passa utmärkt för apparater), tycks kritiken haft begränsad verkan. Den har mest slagit igenom på sina egna fält. Enligt modellen har vi en sändare som skickar ett meddelande från ena sidan, ett medium i vilket det kodade meddelandet transporteras och eventuellt utsätts för brus, och slutligen en mottagare i andra änden som avkodar meddelandet. Utifrån denna modell kan man tänka sig att meddelandet har en viss struktur men avkodas på fel sätt. Man kan också tänka sig att meddelandet avkodas riktigt, och alltså förstås på samma sätt i båda ändarna, men att deltagarna agerar självständigt i förhållande till denna förståelse. Så kan modellen kombinera meddelandets objektivitet med deltagarnas subjektivitet. Det språkliga meddelandet förstås som ett ting med en objektiv existens opåverkad av deltagarnas förståelse. 
Liksom Volosjinov föregriper Heidegger en kritik av den matematiska kommunikationsmodellen två decennier innan den formuleras: "Meddelandet är aldrig någonting sådant som en transport av upplevelser, t ex av meningar och önskningar, från det ena subjektets inre till det andra subjektets inre" (s. 210). Istället är, menar Heidegger, tillvaron delad redan i talet. Som man lätt ser överensstämmer detta med mina tidigare slutsatser. Heidegger kommer dock till sin uppfattning från ett annat håll. Han vinner den ur en kritik av den förment neutrala reflektionen över objekten. Därmed drabbar kritiken inte bara språket, utan all mening överhuvudtaget.

För Heidegger finns ingen ren blick eller fördomsfritt seende. I förståendet ser vi alltid något som något. Vi ser till exempel en stol som en stol. Även i hörandet förstås ljuden genom sina som: vi hör nordanvinden, den knarrande vagnen, den sprakande brasan osv. Att tänka bort detta seende synes omöjligt ens som tankeexperiment. Som mest kan det tillfälligt träda i bakgrunden när vi prövar nya möjliga förståelser. Genom att på detta sätt belysa den dagliga erfarenheten finner Heidegger fenomenella belägg för sin tes: förståelsen är inte en avspegling av tingen, tingen framträder först genom förståelsen. Man kan här frågande invända om vi verkligen alltid förstår på detta sätt. Kan vi inte stöta på något helt och hållet oförstått? Heidegger är inte explicit, men troligen skulle han svara: givetvis kan vi upptäcka okända ting och fråga oss vad de är, men i så fall förstås de som något icke-förstått vilket ändå är bestämt som en viss sorts fenomen och blir som sådant genast föremål för en viss sorts uttolkningsarbete; det okända i största allmänhet är vad som ännu inte är upptäckt. Det på detta sätt förstått icke-förstådda kontrasterar dock mot världens huvudsakliga förståddhet.

Omständigheten att förståelsen alltid redan är befintlig kallar Heidegger för tillvarons som- eller för-struktur. När vi utlägger vår förståelse $\mathrm{i}$ ett yttrande är därför sanningen delvis redan utlagd, innan den inlemmas i yttrandets predikationer: de tematiska utsagorna. Denna struktur är nödvändig för att sanning överhuvudtaget ska kunna uppfattas. "Sanning betyder i dag och sedan gammalt kunskapens överensstämmelse med saken. Men för att båda iakttagandet [das Erkennen] och den sats som formulerar och utsäger kunskapen [die Erkenntnis] ska kunna anpassas till saken, och för att saken själv dessförinnan ska kunna bli bindande för satsen, så måste ju ändå saken själv visa sig sådan som den är" (1987:48). Eller som Heidegger uttrycker samma tanke på ett annat ställe: för att vi ska kunna formulera en sats om $\mathrm{x}$, måste vi alltid redan ha att göra med x; satsen om x förmår endast vara 
sann - dvs. vara i överensstämmelse med $\mathrm{x}$ - eftersom en viss sanning om x redan är frilagd (1984:126f). ${ }^{11}$

Först ger Heidegger fenomenella belägg för att tillvaron alltid redan uppehåller sig i förståelsen. Därefter påvisar han att denna förstruktur redan rymmer en viss sorts sanning och att detta är förutsättningen för alla ytterligare sanningsanspråk (jfr 1992:282). Tillvaron är alltså inte först i ett vimmel av förnimmelser, som den bringar reda inom, för att sedan bygga en "språngbräda, från vilken subjektet kan skutta iväg, för att så omsider nå fram till en "värld"” (1992:212). Vad det gäller att inse är att sakernas som inte är något som klistras på - vore det aldrig så momentant! - utan att sakerna är i tillvaron genom sina som. Det är inte så att tillvaron först och främst "är" och sedan "då och då får lust att upprätta en 'relation' till världen” (s. 83).

Sammanför vi Heidegger och Bachtins idéer, får vi ett sammansatt argument mot den matematiska kommunikationsmodellen. För det första är var och ens förhållande unikt. För det andra är redan detta att förhålla sig att förstå. Det finns ingen språngbräda, ingen ren reflektion. Att vara är att vara i världen genom en alltid redan unik och befintlig förståelse. Mot denna situation balanserar dock språkets konstitution av alla som såsom gemensamma som eller med andra ord såsom gemensam förståelse. Det finns individuella och ömsesidiga moment i varje förståelse. Vad den dialogiska och hermeneutiska uppgiften kommer an på är att finna en rimlig balans mellan de två sidorna. Det gäller här att utöva ett svårt stycke balansakt.

Heideggers ontologi plockas som bekant upp av Gadamer (1986a) som gör den till ledstjärna i sin egen hermeneutik. Om Heidegger gjorde fenomenologin hermeneutisk, gjorde Gadamer hermeneutiken fenomenologisk. Gadamer presenterar alltså inte en ny metod för texttolkning. Han utvecklar en allmän kunskapsteori. Den handlar inte så mycket om hur vi borde tolka som om hur vi måste tolka oavsett våra viljor och val (1986c:438). Fastän Gadamer ofta går i Heideggers fotspår utvecklar han hermeneutiken långt och vida. Den hermeneutiska cirkeln hamnar i ett nytt ljus och antar en levande karaktär. Snarare än att vi spelar ett språkspel, vill Gadamer säga att spelet spelar. Vi kastas in i förståelser. Vi fängslas av dem. Och vi har ingen möjlighet att värja oss. När "wir wissen wollen, was wir glauben sollen" har vi redan kommit försent (1986a:494). Vi kan endast ta oss vidare, anlända vid nya förståelser, i en ständig rörelse av cirklar. I denna tolkningsprocess fäster Gadamer (1995) stort avseende på dialogen med andra förståelser. Vi förstår genom att förstå den andre. I detta skiljer han sig från 


\section{Andreas Widoff}

Heidegger som snarare uppfattar medvaron som ett hinder för tillvarons frihet. En dialogisk språkvetenskap intar av förklarliga skäl Gadamers ståndpunkt.

Redan citatet av Schlegel som inledde undersökningen avslöjar huvudproblemet som Heidegger och Gadamer ställer språkvetenskapen inför: att föra samman grammatik och hermeneutik. Frågan är hur det ska gå till. Är de inte två skilda metoder som hänför sig till erklären respektive verstehen? Skulle de mötas på halva vägen? Om det gällde Schlegels förståelse av hermeneutiken som tolkningslära vore det kanske möjligt. Men nu talar vi om en hermeneutik med universella anspråk som kunskapsteori. Så något sådant möte kan knappast komma till stånd. Här måste vi istället framhålla Heideggers och Gadamers hermeneutiska gest, den gest Ricœur beskrivit som "en ödmjuk handling som är medveten om att all mänsklig förståelse är underkastad de historiska förhållandena under ändlighetens välde" (1988:144). Hermeneutiken måste omsluta grammatiken. Eftersom vetenskapen alltid befinner sig i den alldagliga förståelsens förstruktur, kan endast hermeneutiken hjälpa oss att förstå hur vetenskapen hanterar sin prekära situation. Om man inte godtar denna premiss är det svårt att föreställa sig hur språkvetenskapen arbetar sig fram till sina kunskapsobjekt. Då hamnar man istället $\mathrm{i}$ den ofta omedvetna och naiva föreställningen att kunskapsobjekten är isolerade företeelser i verkligheten - att de finns "där ute" åtkomliga för vårt neutrala perspektiv. En sådan föreställning blir lätt kolossalt eklektisk (om den tillerkänner många av kunskapsobjekten samma giltighet) eller mycket intolerant (om den inte vill befatta sig med några andra kunskapsobjekt än den egna disciplinens). Frågan är nu var denna tolkning tar sin början.

\section{Språkbruket som ontologisk grundval}

Innan vi undersöker hur vi tolkar på skilda sätt, är det lämpligt att försöka besvara frågan om varifrån vi tolkar. Med detta "varifrån” avses den ursprungliga grundstruktur ur vilken kunskapsobjekten kan formas. Så vilken är denna struktur? Vad kan tillerkännas en annan ursprunglighet än disciplinernas skiftande kategorier?

Varje sådan ontologisk fråga måste naturligtvis besvaras med försiktighet. Här har jag förberett den genom flera negativa avgränsning-

ar: gentemot dikotomin system-bruk, gentemot abstrakt-formalistiskt systemtänkande och gentemot subjektivism och objektivism. Gentemot dessa tankemodeller söker jag en enhet som kan förstås i ett existenssätt som är förenligt med olika sätt att tolka. På så vis ska tolkningarnas 


\section{Lingvistik, dialogism, hermeneutik}

ursprung inte förbli ett oförklarat tomrum, även om inte alla tolkningar prompt måste accepteras och försonas. Det gäller här först att förstå hur de kommer till. Sedan kan man möjligen fälla sina omdömen.

Denna eftersökta enhet föreslår jag vara språket som bruk. De positiva argumenten för detta förslag är två. För det första är bruket av språket så givet att det omöjligen kan avvisas. För det andra är dess framträdelse så omedelbar att den måste vara utgångspunkt för varje förståelse. Medan liknande utsagor tidvis har framförts med eftertryck, har de förblivit märkligt outforskade med en hermeneutisk blick på språkvetenskapen. Det är detta företag jag nu tar mig an.

Eftersom begreppet bruk inte längre ingår i dikotomin systembruk, måste definitionen genast vändas över ända. Annars vore den dialogiska och hermeneutiska teorin inte mer än antitesen av den moderna lingvistiken och skulle som sådan bli negativt bunden till denna tradition. Detta omvändande moment brukar förbises av forskare som för övrigt motsätter sig det snäva systemperspektivet. Dikotomin lever kvar i en försvagad form. Till och med Gadamer begagnar den - förvisso något flyhänt utan att tränga in i frågan - i samma andetag som han framhåller brukets primat (1984:321). Och i sin samtalsgrammatik understryker Lindström att system och bruk knappast kan skiljas åt, för att i nästa stycke säga att systemet manifesteras av bruket (2008:11f). Ett särskilt intressant exempel är Svenssons (2010) som skriver om språkvetenskapliga analysperspektiv inom satsgrammatik, textforskning och språkhandlingsteori. Han antar bruket som det ontologiskt givna, men rör sig ändå med både bruk- och systembegreppet. Systemet tänker han sig som abstraktion och långtgående generalisering och bruket som partikulär beskrivning där "empirin i sig utgör forskningsfokus" (s. 41). Vad han huvudsakligen diskuterar är alltså inte de ontologiska begreppen, utan två olika kunskapsformer. De ontologiska föreställningarna kan dock inte undgå att följa med. Genom framställningens dubbla brytning hålls inte varat som sådant (ontologins intresse) och kunskapsformerna (epistemologins intresse) tydligt isär. $\AA$ ena sidan beskrivs system-bruk som olika slag av kunskap, där systemet följer av ett nomotetiskt perspektiv och bruket av ett idiografiskt. $\AA$ andra sidan beskrivs de som existenssätt, där Svensson antar bruket som det enda givna. Precis här uppstår framställningens stora krux. Eftersom en klar distinktion saknas sammanblandas bruket med idiografins partikularitet och härigenom förbigås möjligheten av ontologisk regelbundenhet. Men hur kan vi utan en sådan regelbundenhet förklara existensen av fungerande språk? Det låter sig knappast göras. 


\section{Andreas Widoff}

Denna invändning vore systemanhängarnas trumfkort. De skulle mot Svensson kunna anmärka att han har lämnat en lucka och inte har någon möjlighet att förklara hur språket flyter på och hur vi för det mesta förstår varandra någorlunda problemfritt. Detta vore ett kraftfullt argument. Men eftersom också systemet från den hermeneutiska synpunkten är oförklarat kan inte undersökningen stanna här. Istället måste bruket förstås som enheten av abstrakt och konkret betydelse, som dubbelt betydande språk. Bruk innefattar såväl språkelement som språkinstanser. Det handlar inte längre om en dikotomi, men väl om en tydlig dualism. Bruket definieras i termer av två poler, men med mellanliggande positioner. Därför kan vi tillägga: Bruk innefattar dessutom språkenheter $i$ kontinua mellan språkelement och språkinstanser. Bruket är en kontinuerlig helhet av ömsesidig betingning. Vi förvissar oss om rimligheten i denna formulering, eftersom ett yttrande med vissa språkelement inte endast betyder något helt unikt och samtidigt precis detsamma, utan också ungefär detsamma som andra yttranden med samma språkelement. Yttrandets mening bildas av sammanhang som överskrider den partikulära situationen men som inte omsluter språkets totala sammanhang. Dessa sammanhang ska jag kalla språkmedianer. Precis hur sådana sammanhang avgränsas är oväsentligt. Tvärtom är det väsentligt att de avgränsas på många olika sätt. Låt det röra sig om en familj, en arbetsplats, en subkultur, en diskurs, en genre osv. Denna variation speglar betydelsernas mångfald.

Undersökningen har nu utvecklats en bra bit med hjälp av begreppen abstrakt och konkret. Till sist förpliktar detta till svar på en elementär fråga. Vad innebär de egentligen? Vad vill det säga att en betydelse är "abstrakt" eller "konkret"?

En sak är redan given: det abstrakta är allmänt, det konkreta individuellt. Denna förståelse var nämligen utgångspunkten. En viss alldaglig föreställning är däremot inadekvat: den som förklarar skillnaden i termer av förnimbart och oåskådligt. Föreställningen är problematisk av många skäl, men det räcker här att påpeka att både abstrakta och konkreta betydelser är verksamma i de fysiska material som uppbär deras yttre tecken. Begreppsförståelsen jag söker finns istället i den hegelianska traditionen. Denna har funnit en mycket koncis formulering hos Marx: "Det konkreta är konkret eftersom det utgör sammanfattningen av många bestämningar" (1971:31). Formuleringen kan ge illusionen av att det konkreta är resultatet av en sammanfattningsprocess. Men Marx är här tydlig. Detta är en villa som härrör från tänkandets eget sätt att gå

tillväga: först upplöses det konkreta till abstrakta bestämningar, sedan 


\section{Lingvistik, dialogism, hermeneutik}

återskapar (i bästa fall) tänkandet det konkreta i en syntes av abstrakta bestämningar. Denna konkreta slutpunkt utgör i själva verket också utgångspunkt. Traditionen efter Marx understryker att det vetenskapliga tänkandet inte kan stanna vid abstrakta scheman - "som lämnar verklighetens rikedom åt sidan" (Kosík 1979:70) - utan att den måste återföra dessa till den konkreta verkligheten. Endast så kan det konkreta förstås i sin mångskiftande regelmässighet. En verklighet förstådd på detta sätt är något annat än verkligheten tagen såsom den omedelbart framträder för den alldagliga förståelsen. Det är varken ett abstrakt tänkande uppe bland molnen eller en naiv realism; det är ansträngningen att genom vetenskapen förstå verkligheten i dess fulla komplexitet. Därmed är inte sagt att den vetenskapliga förståelsen någonsin kan bli fullkomlig, utan endast att den eftersträvar ett helhetsgrepp (Kosík 1979).

Begreppet om det konkreta har en del likheter med begreppet överbestämning, som först användes av Freud (2002) för att framhålla drömtydningens svårigheter och som sedan på nytt introducerades av Althusser (1965) i en kritisk diskussion av Hegels dialektik. I den kritiska diskursanalysen har senare Fairclough (2010) funnit begreppet användbart. Överbestämning innebär att ett förhållande bestäms av många olika faktorer, och att det därför kan vara svårt att utröna dess orsaker. Genom att erkänna denna komplexitet undviker man att förfalla $i$ ett simpelt omhuldande av någon enstaka orsak. Denna inställning kunde inte kontrastera mer mot Saussure. Något sådant som överbestämning skulle han bestämt inte vilja veta av. Från hans synpunkt framställer en mångsidig förståelse objekten som "en suddig massa av oregelbundna föremål utan inbördes förbindelse" (1970:32). Men därför saknar Saussure också verktyg för att förstå det enskilda yttrandet på något annat sätt än såsom det bestäms av la langue.

Det konkreta är alltså en mångfald av abstrakta bestämningar. Eftersom förståelsen av det konkreta måste fatta en bra del av - om än inte den fulla vidden av - denna mångfald, råkar den på fler betydelser än förståelsen av det abstrakta. Det konkreta har en större betydelserikedom än det abstrakta. Riktigheten av denna utsaga övertygas man om genom att det konkreta yttrandet inte begränsar vare sig vetenskapens eller vardagens möjligheter. Det kommer till användning för vad helst man önskar: lustläsning, grammatik, filologi, litteraturteori, genreanalys, samhällsvetenskap osv. I den abstrakt tolkade satsen - satsen i egenskap av språkelement - är däremot vägarna stängda förutom till grammatiken och en och annan filosofisk utläggning. 


\section{Andreas Widoff}

Enligt en gammal doktrin uppgår betydelsen till det menade. En annan tänker gärna att den uppgår till det betecknade. En tredje hävdar att mening måste förstås som ett system av differenser. Ytterligare andra vill därtill foga sanningsvillkor eller språkhandlingar. I bästa fall kombineras idéerna i en nyanserad teori. Men varifrån yttrandets betydelserikedom härstammar förblir obegripligt om man håller fast vid dessa snäva begrepp om betydelse. Begreppet om det konkreta placerar istället betydelsen i världens helhet. ${ }^{12}$ Den möjliga betydelsen är därför knappast någonsin fullt utrönad, men den finns där att hämta in. Yttrandet fångar upp fragment av världens outtömlighet. I varje yttrande finner vi därför tecken på denna verklighet. Från sin unika position bryter yttrandet världen på sitt unika sätt. Världen som bestämmer yttrandets betydelse, och världen som yttrandet bestämmer betydelsen av, är $u t$ talad även när den inte är omtalad. Om det inte vore så funnes aldrig något sådant som värderingar av yttranden eller konsten att läsa mellan raderna. ${ }^{13}$ Allt detta som uttalas är ständigt under förhandling - och ofta så mycket mer än det omtalade, som ju brukar vara av en orubbligare art. Endast till liten del handlar språket om att peka på saker i världen. Huvudsaken är den uttalande förhandlingen om detta utpekade. Därför är mötet i det konkreta språket inte en beskedlig sammanfattning av abstrakta bestämningar. Det konkreta språket är en tummelplats för abstrakta bestämningar.

Sannolikt avser Volosjinov något liknande när han skriver att ordet inte endast speglar utan också bryter verkligheten. Ordet återger inte endast ett objektivt och självtillräckligt innehåll. Det anlägger också en synpunkt. I det sociala livet genomborras ordet av synpunkter så att det sönderfaller i ett komplex av synpunkter i konflikt. Ordet är ett mikrokosmos av social kamp (1983b:144ff). Tyvärr är det något oklart om Volosjinov talar om det abstrakta eller konkreta ordet. I min förståelse tar han det konkreta ordet som startpunkt, men låter sedan begreppen glida, just därför att han tänker att inte ens det abstrakta ordet kan frigöras från det sociala livet. En grammatisk abstraktion som inte fångar språkets sociala karaktär torde därmed vara en överdriven formalism från Volosjinovs synpunkt. Detta är, om jag läst honom rätt, en radikalare teori än den jag formulerat ovan. 


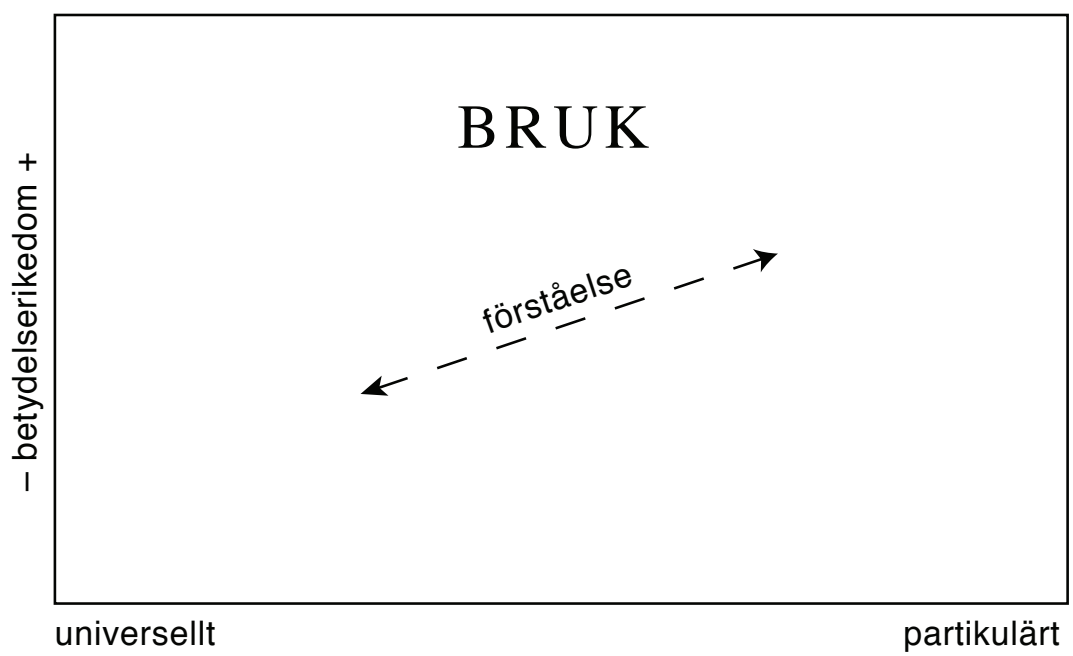

Figur 1. Grunddragen i en kontinuerlig språkmodell. Med ökad generalitet minskar betydelserikedomen.

Dessa utredningar kan nu sammanfattas i en kontinuerlig språkmodell. Grunddragen i denna modell illustreras i figur 1. Modellens fundament är språket som bruk. Detta bruk innefattar två dimensioner: generalitetsgrad och betydelserikedom. När förståelsen är vid det partikulära - där den ursprungligen och vanligen befinner sig - är betydelserikedomen stor. När den rör sig mot det universella minskar samma rikedom.

\section{Tolkningar}

I föregående avsnitt har jag föreslagit ett svar på frågan om förståelsens ursprungliga "varifrån". I detta avsnitt fortsätter jag med att behandla förståelsens "hur". Om det förra ger svar på vad som ligger till grund för språkvetenskapens kunskapsobjekt, besvarar det senare på vilka sätt dess kunskapsobjekt bildas. Språkvetenskapen fortskrider från ett "varifrån" genom ett "hur" till ett "vad". Denna triad låter oss uppfatta förståelsen som ställd inför sin egen möjlighet. Om dess slutpunkt ofta uppfattas som ursprunglig, så beror det på att förståelsen redan har ramlat in i en möjlighet som förblir oreflekterad, eller på att förståelsen som vid en punkt förstod sin möjlighet alltför mycket vant sig vid sig själv. Detta uppenbara att förståelserna skiljer sig åt fordrar dock att vi undersöker hela kedjan, för att så förklara hur dessa skillnader kommer till stånd. 


\section{Andreas Widoff}

Följaktligen finns mängder med skilda kunskapsobjekt, inom såväl språkvetenskapen som andra humanvetenskapliga fält, som har bruket som ursprungligt objekt. Den kontinuerliga språkmodellen bestrider att de skilda kunskapsobjekten skulle vara oförenliga. De tillhör inte radikalt skilda sfärer och kan därför föras samman utan att man blandar samman. Detta är en förening på fundamental nivå. En förening av teorier är det däremot inte. Modellen hävdar inte att det skulle råda ett omedvetet samförstånd. Den anför snarare en grundval för försoning. Det är kanske en smula ironiskt, men det är just här som den teoretiska striden tar vid.

Mitt något gadamerska tillvägagångssätt kontrasterar mot den habermaska begreppsapparat som Svensson (1988) anlägger i sin inventering av nordistikens discipliner. Denna begreppsapparat innefattar tre vetenskapstyper: empiriskt-analytiska vetenskaper, historiskt-hermeneutiska vetenskaper och socialvetenskaper. Dessa antas verka enligt varsin forskningslogik, som skapas av skilda kunskapstyper (nomotetisk, idiografisk, nomotetisk), kunskapsnormer (förutsägelse, förståelse, värdering) och kunskapsintressen (tekniskt, praktiskt, emancipatoriskt). I åtminstone våra dagar är sådana begrepp allmänna i vetenskapernas självförståelse. På så vis kan Svensson sätta in disciplinerna i ett större sammanhang utan att samtidigt, får man förmoda, reta upp dem alltför mycket. Detta har sina fördelar. Beskrivningen börjar dock först vid förståelsens "hur" och förbigår den alldagliga förstruktur som vetenskapen enligt hermeneutiken måste arbeta utifrån. Den undersöker inte hela den tolkningstriad som jag beskrivit ovan. För att kunna göra detta har jag istället fått drista mig till att formulera en språklig ontologi, som jag antar som gemensam grundval för alla discipliner med språket som studieobjekt.

Denna grundval kan förefalla grov: i de två dimensionerna generalitetsgrad och betydelserikedom försvinner onekligen många nyanser. Men åtminstone i detta inledande skede är grovheten nödvändig för att vi ska kunna överblicka tolkningstriaden. Vi kan nu se att olika sätt att bedriva språkforskning är olika förhållningssätt till ett och samma språkbruk. Därefter påträffar vi de olika förhållningssätten inom en begränsad uppsättning elementära tolkningsmöjligheter. Dessa möjligheter kallar jag för tolkningstyper. Jag har identifierat sex sådana typer, som är fördelade på två klasser (figur 2). 

A) Universaliserande tolkning
B) Generaliserande tolkning
tolkningsfält
C) Partikulär tolkning
1) Identitetssökande tolkning
2) Genomsnittlig tolkning
tolkningslinjer
3) Uppdagande tolkning

Figur 2. Tolkningstyper fördelade på två klasser.

Namnen på klasserna härrör från att det är naturligt att tänka sig tolkningsfälten som områden för tolkning och tolkningslinjerna som program för tolkning. Tolkningsfälten rör identitet och variation genom situationerna, tolkningslinjerna identitet och variation genom upplevelserna. Men enklast förklaras skillnaden genom deras primära orientering i modellen: tolkningsfälten orienterar sig utmed skalan av generalitet och tolkningslinjerna utmed skalan av betydelserikedom. Tolkningsfältens primära orientering innebär dock att de sekundärt antar en viss orientering utmed den andra skalan. Tolkningsfält och tolkningslinjer är komplementära: varje tolkning är dubbelt bestämd av en typ ur vardera klassen. Allt detta illustreras i figur 3.

Universaliserande tolkningar ${ }^{14}$ är inriktade på språkelementen och hänför sig vanligen till grammatiken. Men även inom filosofin förekommer denna orientering. Generaliserande tolkningar avser språkmedianer. Hit hänför sig bland annat genre- och diskursanalys. Partikulära tolkningar befinner sig vid kommunikationens ursprung: vid språkinstanserna. De tolkar yttrandet i sig. Identitetssökande tolkningar försöker fastställa språkenheternas gemensamma kärna: den betydelse som antas vara identisk i varje unik tolkning. Genomsnittliga tolkningar är det slags uppmärksamhet vi har som mest: i arbetet, på seminariet, på krogen, vid middagen, när vi talar med expediten osv. Även om dess grund är den alldagliga förståelsen kan vetenskapen finna sig tillrätta här. Uppdagande tolkningar, slutligen, försöker vinna nya betydelser ur språkenheterna. Detta är inte detsamma som friläggandet av dolda mekanismer, utan snarare inställningen att språkenheternas betydelser inte nödvändigtvis är givna, att de också kan utvecklas till något annat. Det är tolkningen som skapande och upptäckande förmåga. Medan partikulära och generaliserande tolkningar har stora möjligheter att växla mel- 
lan tolkningslinjer, är de universaliserande tolkningarna för det mesta identitetssökande. Några olika slag av kombinationer av tolkningstyper berörs i de följande avsnitten.

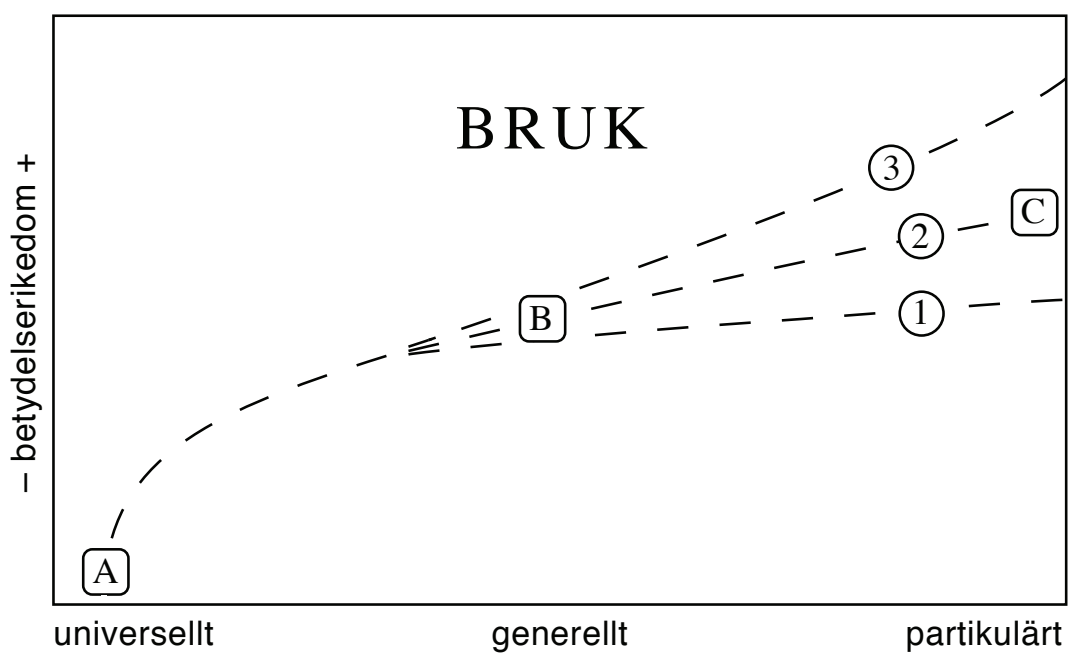

Figur 3. Tolkningstypernas orientering i den kontinuerliga språkmodellen.

Tolkningstyper är inte samma sak som tolkningsmodus, som är hela tolkningsförfarandet såsom det brukar ske i en viss praktik eller såsom det föreskrivs av en skolbildning. Till vetenskapligt anvisade tolkningsmodus kan vi räkna grammatisk analys enligt det minimalistiska programmet, psykoanalytisk litteraturanalys och historisk-grammatisk bibelexeges. Dessa kontrasterar mot andra vetenskapliga tolkningsmodus såsom analys enligt huvuddriven frasstrukturgrammatik, narratologisk litteraturanalys och kristocentrisk bibelexeges. Ingen enskild tolkning kan vara utan sådana specifika bestämningar som hänför sig till något utöver tolkningstypen. Tolkningen har alltid också sitt modus. Detta gäller även de genomsnittliga och partikulära tolkningarna, om de så bara bestäms av tillvarons tillfälliga stämning, som kan vara sorgsen, upprymd, intresserad osv (jfr Heidegger 1993 § 29).

De sex tolkningstypernas enda särdrag är inte att de har skilda mål. På vägen till dessa mål genomgår de allmänt taget skilda tolkningsprocesser. De måste få olika saker uträttade och stöter därmed på olika typer av problem. Många av dessa skillnader framgår i de följande avsnitten. Ett avgörande problem ska dock uppmärksammas redan nu. Detta problem betingas av de speciella mentala existensvillkoren för universella och generella betydelser. För att förstå detta kan det vara 


\section{Lingvistik, dialogism, hermeneutik}

till hjälp att aktualisera en distinktion från Husserl (2000). Husserl skiljer mellan betydelser som vi endast upplever och betydelser som vi är medvetna om på ett föremålsligt sätt. Språkinstanser hör till den senare kategorin: de är det relevanta i situationen och därför i centrum för vår uppmärksamhet. Samtidigt med denna uppmärksamhet upplever vi dock språkelement och språkmedianer såsom en nödvändig bakgrund till den partikulära betydelsen. Att ha dessa abstrakta språkenheter i centrum för vår uppmärksamhet är däremot ett undantag, som på många sätt är främmande för vårt vanliga sätt att förstå. När vi omorienterar vår uppmärksamhet och vill redogöra för dessa måste vi därför ta till uttryck anpassade för "det normala intressets sfär, dvs. till de föremålsligheter som framträder där" (s. 64). Även om vi utvecklar formella system och rika terminologier, är vi i slutändan hänvisade till ett språk som inte är skapat för meddelelse av generella betydelser. Detta är en svårighet som inte bara filosofer, utan också språkforskare måste kämpa med. Detta blir påtagligt när jag i anslutning till den universaliserande tolkningen ställer frågan om språkelementens natur.

Vetenskapliga tolkningsprocesser kan vidare delas in i två akter. Först genomgår de en meningsgivande akt. Denna är grundläggande $\mathrm{i}$ dubbel mening: dels som adjektiv i meningen 'som resten vilar på', dels som presens particip i meningen 'som lägger grunden för'. Den förbereder den fortsatta tolkningen genom att på sitt för typen särskilda sätt fråga: "Vad betyder detta?" Därefter genomgår tolkningsprocesserna en strukturerande akt som ställer frågan: "Hur hänger språkenheterna på denna nivå samman?” Den strukturerande akten bestäms i mindre utsträckning av tolkningstypen; dess särskilda prägel kommer från specifika tolkningsmodus. Den kontinuerliga språkmodellen betonar den meningsgivande akten, som annars ofta smusslas undan, genom att förutsätta att denna måste föregå struktureringen. Grammatiken, genreanalysen eller den idiografiska textbeskrivningen kan enligt denna uppfattning inte omedelbart påbörja sin strukturering. Först måste förståelsen vara av ett sådant slag att den vet vilken betydelsetyp tolkningsföretaget gäller. Struktureringen förutsätter att förståelsen redan har inrättats på en viss position $\mathrm{i}$ brukets helhet.

Innan undersökningen går över till de enskilda tolkningstyperna, vill jag förekomma en tänkbar invändning mot tolkningstypologin som helhet. Jag tecknar bilden av en enkel addition av betydelser från universella till partikulära och från identitetssökande till uppdagande tolkningar. Detta kan förefalla simplistisk. Om man antar Sonessons (2002) terminologi som ställer additiva mot reviderande tolkningar, 


\section{Andreas Widoff}

kunde man hävda att modellen förbiser de senare. Sonessons uppenbara exempel på revideringar är metaforer och ironi. Även om inte alla metaforer inträffar i rörelsen från abstrakt till konkret (en del förstås redan på språkelementens nivå) är detta nästan alltid fallet vid ironi.

Ironi innefattar en diskrepans mellan två nivåer av betydelser. Låt oss anta att dessa nivåer är en "förväntad" betydelse (som bestäms av språkelementen) och en avsedd betydelse (som man i bästa fall kan sluta sig till på språkinstansernas nivå). Från abstrakt till konkret sker alltså en revision. För att denna revision ska kunna uppfattas, måste språkinstanserna hänvisa till språkelementen. Det måste finnas tecken på att revisionen har skett. Den mest ekonomiska analysen, som dessutom är i överensstämmelse med mina tidigare antaganden, är att hänvisningen är intern. Den föreligger i språkinstanserna som sådana. Godtar man detta sker ingen radikal revision när man går från språkelement till språkinstanser; de senare bär hela tiden med sig de förra. I denna mening är förhållandet fortfarande additivt. Revisionen är ingen radikal revision, utan snarare namnet på den särskilda ironiska relation som upprättas mellan abstrakt och konkret inom språkinstansernas ram. Så långt tycks modellen hålla.

Värre är det med rörelsen från identitetssökande till uppdagande tolkningar. Här måste jag erkänna möjligheten av en radikal revision. En uppdagande tolkning måste nämligen kunna sluta sig till att man i själva verket ingenting vet eller i varje fall vet mycket mindre än man först trott. Detta är ett fall som förbises i det följande. Min underlåtenhet förklaras delvis av utrymmesskäl. Men den försvaras också av att uppdagandets tendens i praktiken ändå är att utöka vår förståelse, inte att undandra den dess anspråk (jfr Gadamer 1986b).

\subsection{Universaliserande tolkningar}

En universaliserande tolkning börjar i ett begränsat material - i konstruerade eller autentiska belägg - och framlägger sedan vad som vore detsamma i varje situation. Den fastställer ett konstant innehåll givet ett visst uttryck. Denna konstans avser en identitet som löper genom de skilda sammanhangen. För att verkligen förstå tolkningstypologin måste man vara noggrann med att denna identitet skiljer sig från den som avser en överensstämmelse mellan skilda tolkningar. Denna senare identitet fastställs av den identitetssökande tolkningen. Även om den identitetssökande tolkningslinjen dominerar det universaliserande tolkningsfältet är den inte alldeles ensam. En genomsnittlig-universaliserande tolkning hävdar universaliteten av betydelser som inte är allmänt 
uppfattade. En del vill nog avfärda en sådan tolkning som motsägelsefull och därmed otillbörlig. Men det är just denna som används vid kritiska bedömningar av språkbruket, såsom när något uttryck hävdas ha en fastställd bibetydelse som är klandervärd, fastän många språkbrukare inte uppfattar denna. I det följande behandlar jag universaliserande tolkningar inom den identitetssökande tolkningslinjen. Denna kombination är kännetecknande för grammatiken.

Grammatiken måste först bestämma sig för den identitetssökande tolkningslinjens räckvidd: om den tar ett språk, en dialekt eller en idiolekt i sitt fång. Om den väljer något av de förra alternativen måste den finna en intersubjektiv överensstämmelse i den meningsgivande akten. Efter själva avgränsningen, som är ett förberedande arbete, sker tolkningens kritiska moment: omdömet som forskaren fäller eller låter fällas om materialet. Ett sådant omdöme tillskrivs så gott som alltid en vidare giltighet än sin faktiska räckvidd. Om fem modersmålstalare från olika håll fäller samma omdöme så antar man att detta är giltigt för de flesta modersmålstalare av samma språk. Sådana extrapolationer innefattar en viss osäkerhet: någon ultimat garanti för att inte andra språkbrukare skulle ge ett annorlunda omdöme finns inte. Universaliseringen hjälper dock till att minimera problemet. Dess effekt är just att språkenheterna töms på betydelse, så att endast en liten del blir kvar. Om denna del kan de flesta vara överens. Den universaliserande och den identitetssökande tolkningen har som vi ser en stark affinitet. Att denna del av tolkningsprocessen ofta sker utan problem är säkert en förklaring till att den knappt uppmärksammas inom den moderna lingvistiken. Istället tenderar den att uppfatta den universella betydelsen, inte som produkten av en aktiv tolkning, utan som ett passivt faktum.

Det visar sig att grammatiken lyder under ett intersubjektivt sanningskriterium av särskilt slag. Det rör sig inte om den rent praktiska omständigheten att omdömena måste godtas av en forskningsgemenskap för att ha verkan som vetenskaplig kunskap. Kriteriet är internt. Det ligger i själva föremålet. Man behöver inte vara anhängare av en dialogisk eller hermeneutisk teori för se detta. Föreställningen följer redan med idén om ett konventionellt språksystem. För om konventionerna är forskningens föremål måste forskningen stämmas av mot dem som uppbär dessa. Detta är inte en dialogisk intersubjektivitet, utan en intersubjektivitet av strikt överensstämmelse. ${ }^{15}$

Vi skjuter tills vidare den identitetssökande tolkningslinjen åt sidan och behandlar den universaliserande tolkningstypen för sig. Universaliseringens principiella problem är hur språkelementen ska beskri- 
vas - av vilken beskaffenhet dessa universella enheter är. En föreställning som lätt infinner sig är den om en kärna, som uppenbarar sig i sin obestridliga klarhet, när allt kontingent krafs skalats bort. Men när vi börjar fundera över hur man ska sätta ord på en sådan kärna blir föreställningen allt mer dunkel. Detta visar sig om vi tittar på ett exempel. "Vilken ful hund!" Vi beaktar genast att en sådan sats kan vara ironiskt menad, uppriktig, älskvärd eller utsagd med kraftigt eftertryck, och kanske vid något tillfälle inte ens avser en hund. Ingen förståelig beskrivning verkar kunna ringa in kärnan i alla sådana möjligheter. Samtidigt hade vi knappast problem att föreställa oss en viss betydelse när vi läste exemplet. Vi såg kanske en tax eller en bulldog eller bara en suddig hund med ovanligt ful uppsyn. Vi föreställde oss en prototypisk betydelse. Volosjinov (1973) gör en liknande iakttagelse och menar att vi överhuvudtaget inte kan föreställa oss en universell betydelse utan att placera denna i en prototypisk situation. Även om han härmed avser att framhålla den konkreta betydelsen, kan en prototyp inte likställas med denna. Snarare tycks Volosjinov ha föregripit teorin om semantiska prototyper, som senare formulerades inom psykologin.

Av detta kan man sluta sig till att grammatiken inte rör sig så mycket med kärnor som med prototyper. Grammatikens närmande till det universella är därför asymptotiskt. För att undvika en alltför snårig terminologi kallar jag fortsättningsvis även prototyper för språkelement. ${ }^{16}$

Så här långt har vi endast bekantat oss med den universaliserande tolk ningens meningsgivande akt. Först efter denna kan den strukturerande akten ta vid. Då kan vi för första gången presenteras för språkets grammatik. Den engagerade grammatikern vill kanske insistera på att struktureringen reder sig själv. Säkert kan den också finna flera argument för detta. Till exempel: man behöver inte ha en susning om vad satser som "Krutet står på lustigt lut" eller "Colorless green ideas sleep furiously" betyder - varken som språkinstanser eller språkelement - för att kunna sluta sig till ett och annat om deras grammatik. Det är sant. Men skulle det gå att inte ha en susning om en enda sats i språken och ändå sluta sig till något om satsernas grammatik? Grammatikern får gärna lov att försöka med ett språk som den inte förstår och som inte i förväg blivit uttolkat av en medhjälpare. Det kommer givetvis inte att gå. Grammatikern kan inte annat än att utgå från förståelsens alldagliga förstruktur. Endast på denna grund kan den anlägga sitt perspektiv: först universalisering till språkelement, sedan strukturering av språkelement. 


\section{Lingvistik, dialogism, hermeneutik}

Även grammatiska modeller med biologiska anspråk tar denna väg till teorin. Deras huvudsakliga metod är nämligen (i strid med anspråket kan tyckas) introspektion.

\subsection{Generaliserande tolkningar}

En generaliserande tolkning kan vara mer eller mindre generaliserande. Den kan exempelvis rikta in sig på ett språkligt register. Men den kan också förklara att Johanssons brukliga kommentar "Det var inte så tokigt" i själva verket är ett mycket gott omdöme; den kan generalisera om en individs sätt att tala. Överlag skiljer sig generaliserande tolkningar mycket åt. Sådana som är mycket generaliserande kan ansluta sig till universella tolkningsmodus, medan de som är mindre generaliserande kan låta sig influeras av partikulära tolkningsmodus. De kan också grunda sig i särskilda generella tolkningsmodus, såsom genreteorin och diskursanalysen. Om ett tolkningsmodus är gränsöverskridande - om den rör sig mellan tolkningstyper - kommer den helt säkert att passera den generaliserande tolkningen. Ett exempel på det senare är textlingvistiken.

När van Dijk (1972) inledde sina textlingvistiska undersökningar var syftet att ge en universell beskrivning av texters struktur. Det var en grammatik för en enhet större än satsen. Men mycket snart - redan som del två i samma avhandling - övergick undersökningen till textkomposition på genrenivå. Därmed transponerade van Dijk det universella tolkningsmoduset till en generaliserande tolkningstyp. Varken den inledande ansatsen eller transponeringen har dock varit alldeles problemfria. Det torde vid det här laget stå klart att textlingvistiken har svårt att upprätthålla den långtgående generalisering som dess tolkningsmodus eftersträvar. Detta problem har kommit en textlingvist som de Beaugrande att tvivlande resonera: "The postulate that language can be separated from language use ... may prove to be so fundamentally misconceived that a large part of linguistics research cannot support the theoretical claims based on it. Grammar appears to be a body of fuzzy knowledge that assumes clear forms when put to everyday uses, but tapers off when applied to less familiar and controllable patterns ... If so, grammar doesn't exist, except as a derived construct of grammarians, until it is used in some language event" (1984:238f). Som jag läser detta menar de Beaugrande att de grammatiska konstruktionerna möjligen är fiktioner i sin eleganta formalism, inte att ingen som helst språklig regelbundenhet skulle råda. Att just en textlingvist reser denna fråga är 


\section{Andreas Widoff}

nog ingen en slump. Textlingvistiken rör sig inom generalitetens hela spektrum: från det universella till det partikulära. Den försöker finna allmänna regler för texters komposition, men stöter på problem när den konfronteras med unika texter, vars partikularitet är betydligt svårare att förbise än de autentiska satsexemplens. Textlingvistikens praxis gynnar därför idén om kontinua av regelbundenheter mer än idén om tillfälliga tillämpningar av ett fast regelsystem. Från att först ha sett sig själv i gränslandet mellan system och bruk, hamnar den i tvivel och undrar om det inte alltid är detta gränsland som språket befinner sig i.

Textlingvistiken är alltså ett tolkningsmodus som kan vara både universaliserande och generaliserande. Dessutom tvingas den hantera det märkbart partikulära. Jag har diskuterat den för att illustrera tolkningstypernas tidvis suddiga gränser. Två mer typiskt generaliserande tolkningsmodus är genreteorin och diskursanalysen.

Vanligen tänker vi väl på genrer som olika slag av syntagmatiska konfigurationer: de hänger samman med en viss komposition. Vi brukar också anta att de uppvisar typiska språkliga drag. Detta brukar gälla även när genrens koppling till den sociala verksamheten framhålls som definierande kriterium (t.ex. Martin \& Rose 2008 och Ledin 1999). Jag invänder inte mot något av detta. Men genren är också språkmedian och genrens delar är språkmedianer. Att genreanalysen måste tolka sig fram till dessa ser vi genom att återigen understryka den meningsgivande akten.

Liksom den grammatiska analysen utgår genreanalysen från ett begränsat material. Den har några texter till handa. Men för den generaliserande tolkningen i genreanalysens modus är inte dessa några texter rätt och slätt. De är exempel på... Tolkningen söker en betydelsenivå som låter den syntagmatiska regelbundenheten framträda. Den kan inte endast förstå "1 kg morötter" som språkelement. Den kan inte heller förstå "1 kg morötter" som språkinstanser. Den måste förstå detta som en "ingrediens" i en "ingredienslista". Först därmed kan den efter hand komma fram till att ingredienslistan är del av en språkmedian som kännetecknar genren recept. Denna bestämning kan tyckas vagare och mer generell än språkelementen " 1 kg morötter". Men det handlar här om åtminstone en dubbel bestämning. Vi måste skilja mellan språkmedianerna som bestäms av språkelementen plus genrekategorin och dessa bestämningar sedda var för sig. Vad detta tolkningsmodus arbetar med är språkenheter som är bestämda på båda sätten, eftersom den knappast kan finna något sådant som ingredienslistor utan språkelement. 


\section{Lingvistik, dialogism, hermeneutik}

Nästa exempel är Foucaults (2002) arkeologiska diskursanalys. Foucault är ett lämpligt exempel i detta sammanhang, eftersom han ogärna låter sig inordnas i modellen. Lyckas modellen betvinga honom är det mer värt än om den konfronterats med en medgörligare motpart. Det är inte bara så att Foucault i största allmänhet sätter sig på tvären till en dialogisk och hermeneutisk ansats; enligt honom befinner sig dessutom de diskursiva formationerna på en annan existensnivå än språket. De diskursiva formationerna organiserar utsagor som inte är språkliga strukturer utan existensfunktioner som bestämmer att de språkliga tecknen kan utsägas (s. 108f). De diskursiva formationerna framställs alltså som ett område utanför den kontinuerliga modellens språkplan. Men från modellens synpunkt är detta inget större problem. Modellen är endast en språkmodell. Det finns mängder med bestämningar - bland annat alla slags sociala förhållanden - som ger sig till känna i språket, men som inte uttöms i sina språkliga framträdelser. Så kan man också förstå Foucaults diskursiva formationer. Ändå kan det verka som att de diskursiva formationerna är en bestämning av bruket som helhet och alltså inte passar in som generell bestämning i modellen. Foucaults egna kommentarer föreslår dock att de är specifika generella bestämningar bland många andra möjliga. När vi analyserar diskursiva formationer undrar vi varför just vissa utsagor har uppträtt och inte andra i deras ställe. De diskursiva formationerna är flertaliga i relation till den entaliga grammatiken. ${ }^{17}$

Ett annat problem med Foucaults arkeologi är att den överhuvudtaget inte handlar om betydelser, om man förstår den på hans eget sätt. Men från modellens synpunkt är detta ett tolkningsmodus som blott i teorin hoppar över tolkningsprocessens meningsgivande akt. Den vill alltför gärna genast ta itu med struktureringen. Tolkningsprocessen är i stora drag densamma som beskrivits för andra tolkningsmodus. För att få syn på en struktur av diskursiva formationer måste man tänka sig partikulära utsagor som exempel på utsagor i diskursen. Utan denna akt kan inte ens struktureringen ta vid. När vi väl tillägnat oss struktureringen (den specifika teorin) kan dessutom en liknande men motsatt rörelse påvisas. Upptäcker vi en utsagas position i en diskursiv formation, upptäcker vi nämligen en av språkinstansernas bestämningar - vi upptäcker deras särskilda existensmodalitet (s. 134). Att detta bidrar till förståelsen av språkinstansernas mening är tämligen uppenbart. Frestas vi inte rentav att säga: det är poängen med teorin. 


\section{Andreas Widoff}

\subsection{Partikulära tolkningar}

En partikulär tolkning stannar vid det enskilda yttrandet. Detta kan ske vetenskapligt - till exempel genom att tolka yttrandet mot bakgrund av några av dess abstrakta bestämningar - eller alldagligt - såsom när vi pratar med varandra eller läser tidningen. I alla händelser abstraherar den partikulära tolkningen inte från yttrandet.

För den alldagliga tolkningen är icke-abstraktionen oumbärlig. Den måste vara uppmärksam på situationen. Samtidigt måste den också vara rask. Därför undviker den inte bara abstraktion, utan vanligen också analyser som skulle stanna vid det konkreta. För analys finns det kort sagt inte tid. Detta tolkningsmodus för våra dagliga bestyr intresserar sällan vetenskapen. Här vill jag bara notera dess existens. Annars riskerar vårt ointresse att bli en paradoxal glömska inför det alltigenom förhärskande sättet att förstå. ${ }^{18}$

En analys av det konkreta kan grovt sett vara av två slag. Å ena sidan kan den uppmärksamma betydelser som är unika för språkinstanserna eller som i varje fall endast bjuder begränsade möjligheter till generalisering. Detta är fallet vid idiografiska textanalyser såsom de brukar te sig inom estetiska och historiska vetenskaper. $\AA$ andra sidan kan analysen förstå yttrandet som en konfiguration av kategorier som härrör från generaliserande och universaliserande tolkningar. Denna metod är vanlig inom språkvetenskaplig textforskning. I det prototypiska fallet är analysen kvantitativ: texten beskrivs som en kombination av språkliga drag i givna proportioner. En sådan analys uttömmer inte närmelsevis den partikulära textens innebörd. Knappt tycks den vidröra dess egenart. Detta inser vi eftersom vi bara behöver läsa texten i den mest håglösa genomsnittlighet för att ytterligare betydelser ska framträda. Den konfigurativa analysen behöver dock inte vara kvantitativ. Många icke-kvantitativa textanalyser är av ungefär samma slag. Sådana undersökningar pendlar visserligen gärna mellan generella språkenheter och språkinstanser. Vi presenteras för unika texter som dels beskrivs som sådana, dels analyseras genom kategorier från språkelementens och språkmedianernas nivå. Undersökningens tyngdpunkt ligger nästan alltid vid det senare. Därmed hamnar texternas unicitet i bakgrunden.

Man kan argumentera att stereotyp bruksprosa med fördel undersöks på detta sätt. Där finns inte alltid så mycket att säga om en enskild text. Då är mönstren det intressanta. Lika enkelt kan man argumentera att samma metod är otillräcklig vid mer originella texter, sådana som bland annat litteraturvetenskapen arbetar med. Det kan inte förnekas att materialet delvis måste bestämma metoden, och att detta är orsaken till 
vissa av skillnaderna mellan språkvetenskaplig textforskning och litteraturvetenskap. Men varken den ena eller den andra metoden är principiellt utesluten i något av fallen.

Den konfigurativa analysen är en fullkomligt godtagbar metod. Men metoder blir lätt idéer som blir oreflekterad doktrin. Därför måste jag understryka att yttrandet inte kan likställas med konfigurationen av generella språkenheter. Även om alla yttranden av någorlunda omfång är just en unik konfiguration sammanfaller inte denna med yttrandets identitet. Omvandlar vi den konfigurativa analysen till teori - något som dess utövare per automatik inte kan anklagas för - definieras yttrandet som resultatet av en sammanfattningsprocess, inte som processens grundval. Otillräckligheten av en sådan teori påvisas av att den står utan något meningsmässigt kriterium för att skilja olika yttranden med identiska språkelement åt. För denna teori är det likgiltigt var och när och vem som yttrar. Sådant inverkar inte på yttrandets identiska betydelse.

Vi kommer alltså tillbaka till frågan om vad ett yttrande är. Det är historiskt, det är partikulärt och framförallt: det är konkret. Yttrandet är en mångfaldig bestämningsstruktur, varav språkelement och språkmedianer endast är en del. Yttrandet har alltid också sin mening. Först på denna grund kan vi förstå den partikulära tolkningen och dess variationer. ${ }^{19}$

\subsection{Identitetssökande, genomsnittliga och uppdagande tolkningar}

De tre tolkningslinjerna är elementärt skilda inställningar till språkenheternas mening. Den identitetssökande tolkningen söker sig mot en kärna av vad språkenheterna alltid är; den genomsnittliga tolkningen förblir mest såsom den redan är, utan intresse att finna något annorlunda; och den uppdagande tolkningen söker efter en fylligare mening, efter betydelser som tidigare varit fördolda.

Att hävda att tolkningslinjerna är elementära på samma sätt som tolkningsfälten är kanske radikalt. Även om språkvetenskapen ofta saknar begrepp för skillnaden mellan abstrakt och konkret, torde alla språkforskare vara bekanta med distinktionen mellan allmänt och enskilt. Få har problem att se vad detta innebär. Med tolkningslinjerna står typologin inför en svårare uppgift. Begreppskonstruktionen är nästan helt obekant.

I någon mån kan Bachtins (2003) idé om centripetala och centrifugala krafter vara till hjälp. Identitetssökande tolkningar hänger samma med de förra, uppdagande med de senare. Men är sammanhållningen 
och spridningen deras funktion eller föremål? Svaret på denna fråga avslöjar en väsentlig asymmetri. För de identitetssökande tolkningarna är sammanhållningen ett föremål. För de uppdagande tolkningarna är spridningen en funktion. Endast sekundärt kan funktion och föremål tillskrivas den andra tolkningslinjen. Den identitetssökande tolkningen visar tillbaka på något som måste ha föregått den själv. I den mån den fungerar sammanhållande är det endast genom att den rekapitulerar vad som redan sammanhållit. Den uppdagande tolkningen däremot har inget klart föremål framför sig. Dess funktion är att skapa detta föremål. Först $\mathrm{i}$ efterhand har föremålet status av betydelse. Den genomsnittliga tolkningen, slutligen, befinner sig mellan dessa sätt att verka. Om den uppdagande tolkningen löper framåt mot det okända och den identitetssökande tolkningen vänder sig om mot ett gemensamt ursprung, så står den genomsnittliga tolkningen stilla. Den har både föremål och funktion men ingen av dessa är särskilt accentuerad. Detta är den språkliga förståelsens normalläge. Den genomsnittliga tolkningen är det så typiska sättet att förstå att den lätt förbises när tolkningen behandlas som problem. Vi läser tidningen, vi hör vad någon säger, och förstår. Det är sällan mer med den saken.

Tolkningslinjerna är svåra såsom begrepp också av ett annat skäl. Vi tänker oss att språk "betyder" och att man sedan "förstår" detta betydande. Samma struktur finns nedlagd också i denna framställning: först språkbruket som ontologisk grundval, sedan en tolkningstypologi. Men som jag underströk innan dessa begrepp introducerades så betyder språk endast såsom det förstås. Begreppen innefattar alltså en motsättning. Med idén om det konkreta som något i praktiken outtömligt och detta outtömliga som föremålet för den partikulära tolkningen börjar motsättningen att ge sig till känna. Med den identitetssökande och den genomsnittliga tolkningen förstärks den ytterligare. Med den uppdagande tolkningen blir den till sist akut. Grunden som "betyder" stiger gradvis upp till aktiviteten som "förstår". De två kategorierna smälter samman till en. Är vi inte försiktiga riskerar vi nu att hamna i den slappaste sortens relativism. Sådana akademiska olyckfall brukar dock bero på att man inte tar vederbörlig hänsyn till två av ytterpunkterna $\mathrm{i}$ tolkningstypologin, nämligen universaliserande och identitetssökande tolkningar. Först när man åsidosätter dessa och ensidigt betonar partikulära och uppdagande tolkningar får man verkligen problem. Beaktar vi båda sidorna samtidigt inser vi att iterativitet och identitet är nödvändiga men inte tillräckliga i varje betydelsestruktur såsom upplevda om än sällan föremålsligt medvetna moment. Utan dem skulle kom- 
munikationen bryta samman. Tolkningslinjerna är således inte olika perspektiv på ett språk som är givet i sin autonoma existens, vilket vore i likhet med variationer i varseblivningen av tingen. De är aspekter av språkets existenssätt. Uppdagandet svarar mot öppenheten, identitetssökandet mot stabiliteten, genomsnittligheten mot smidigheten. Alla tre existenssätten har en roll i den alldagliga kommunikationen, fastän den genomsnittliga tolkningen har en klar förrangsställning.

Låt mig ge några illustrationer på hur tolkningslinjernas figurerar i vetenskapen. Jag har särskilt läsningen och analysen av enskilda yttranden för ögonen. Språkvetenskap och litteraturvetenskap får stå modeller även denna gång.

Inom ett omfattande fält som litteraturvetenskap finns förstås många uppfattningar om vad textanalys syftar till. Ett genomgående drag är väl dock att man gärna vill säga något nytt om texternas unika mening. Att påpeka något som tidigare förbisetts - antingen för att föregångarna varit trångsynta eller för att texterna inte ordentligt beforskats - däri ligger analysens värde. Möjligheten att åstadkomma detta är dessutom så mycket gynnsammare när texterna är litterära och undandrar sig vår förståelse. Effekten av en lyckosam studie är alltså ett klarnande men också en förskjutning av textens mening. En genomsnittlig tolkning skulle aldrig åstadkomma detta. Den skingrar inte dimman och lämnar textens mening ungefär där man först fann den.

Inom språkvetenskapen kan vi finna smärre motstycken inom stilistik och diskursanalys. Retoriken kan möjligen också räknas hit som en angränsande disciplin. Men merparten av textforskningen har en helt annan karaktär. Först sker en läsning på genomsnittligt vis som inte tillskriver texten annat än vad en normal läsare kan uppfatta. Detta är tolkningens meningsgivande akt. Därefter struktureras texten enligt någon viss modell. Här får undersökningen sin vetenskapliga udd. Utan stöd av struktureringen vore den platt. Detta är som tydligast när undersökningen är kvantitativ och lutar sig mot den konfigurativa analys som beskrevs i föregående avsnitt. Först i siffrorna finns vetenskapligt värde. Mycket lite ligger i själva läsningen. Vi måste förstås medge att struktureringen kan vara sekundärt meningsgivande, att den till sist kan modifiera förståelsen av texten, men detta är alltid en marginell förskjutning i jämförelse med den uppdagande tolkningens kraft.

Forskningen behöver förvisso inte vara kvantitativ för att denna karaktäristik ska gälla. Vi behöver bara tänka på Conversation Analysis. Den meningsgivande akten tillför här ingenting som inte deltagarna i samtalet förväntas ha uppfattat. Så långt är tolkningen ointressant. 


\section{Andreas Widoff}

Den strukturerande akten däremot tillför en mycket detaljerad analys av samtalets alla element: en paus på 1,2 sekunder, en talares utandningsljud, en annan talares stakningar osv. Detta intresse för fysiska detaljer kan förleda en att tro att CA huvudsakligen vilar på en identitetssökande grund. Analysens fortsättning visar dock att så inte är fallet. Här introduceras begrepp för organisationen av turtagning, sekvenser, reparation och turdesign. Sådana begrepp är begripliga först från deltagarnas perspektiv. Inom CA betonas dessutom deltagarperspektivet genom att analysen försöker fånga samtalet i dess rörelse, precis såsom det framträtt för deltagarna. Enligt den tagmemiska terminologin, som en del CA-företrädare tagit i bruk, är de förra kategorierna etiska, medan de senare är emiska (Goodwin 1984:243f och Have 2007:34f). Med min terminologi innebär det att de senare begreppen vilar på en genomsnittlig-partikulär tolkning.

Även med detta sagt finns något angeläget i vad som antyddes tidigare. Kvantifiering tycks främmande för den uppdagande tolkningen. Varför? Mot det kvantitativa ställer man vanligen det kvalitativa. Men vad innebär det?

I sin avhandling om svenska pamfletter skriver Gustafsson (2009) att hon tillämpar två metoder: en kvantitativ och en kvalitativ. Den första metoden innebär uppenbarligen att hon presenterar vissa textegenskaper siffermässigt. Den senare metoden innebär att hon gör "en tolkning av varje text” (s. 63). Så långt är allt som det brukar. Men när hon även låter de senare resultaten kvantifieras - eller som hon uttrycker det: "kvantifiera kvalitativa resultat" (s. 235) - så ställs begreppen på sin spets. Vi upptäcker en oroande asymmetri. För om något sådant som en kvantifiering av kvalitativa resultat är möjligt, kan inte begreppen utgöra ett äkta motsatspar, såsom man annars lätt föreställer sig. Kvantitativt-kvalitativt är en ofullbordad begreppskonstruktion. Vi kan pröva att utveckla den med en motsats för respektive term. Mot det kvantitativa ställer vi det icke-kvantitativa, mot det kvalitativa det ickekvalitativa. Det icke-kvantitativa är lätt att föreställa sig: det är resultat som presenteras utan tabeller och statistik. Men det icke-kvalitativa? Finns det något sådant som helt saknar kvalitet? Strikt sett vore det väl ett tomt intet. Men nu kan det knappast vara tomma inten som forskare kvantifierar. Kvantifiering måste alltid vara kvantifiering av vissa kvaliteter. Dessa kvaliteter är däremot vanligen av en annan art än de som hanteras inom den icke-kvantitativa forskningen. Denna skillnad är bakgrunden till Gustafssons formulering. Hon kvantifierar kvaliteter av ett slag som vanligen inte kvantifieras. De typiskt kvantifierade 


\section{Lingvistik, dialogism, hermeneutik}

kvaliteterna är nämligen reducerade innebörder som enklare låter sig formaliseras. Inom språkforskningen hämtas de från universaliserande, generaliserande och identitetssökande tolkningar. Gustafsson har däremot hämtat sina kvaliteter från genomsnittliga-partikulära tolkningar som kanske rentav tenderar mot det uppdagande. Denna metod uppfattas väl lätt som riskfylld, eftersom sannolikheten för diskrepans mellan forskarens och andras tolkningar är stor, samtidigt som tolkningsprocessen inte är fullt exponerad. Om detta tycks Gustafsson vara väl medveten och hon bemödar sig om att förklara värdet av sitt grepp.

Åtminstone i detta språkliga sammanhang rymmer begreppsparet kvantitativ-kvalitativ mer än två metoder. Begreppen innefattar också en föreställning om olika slag av betydelser. Därför berör metoderna sällan samma sidor av språket - de känner sig hemma i olika områden av språkets ontiska struktur. Denna förknippning mellan metod och varande är dock inte tvingande, vilket Gustafssons exempel visar. Som en allmän karaktäristik kan ändå följande hävdas. Den kvantitativa metoden rör sig med universaliserande, generaliserande och identitetssökande tolkningar; den kvalitativa metoden med partikulära, genomsnittliga och uppdagande tolkningar. "Kvalitet" i denna oegentliga mening åsyftar ett rikare betydelseinnehåll som lätt skiftar mellan tolkningar.

\section{Avslutning}

Undersökningen har frågat efter språkvetenskapens kunskapsobjekt. Denna fråga kan besvaras på två sätt: med en uppräkning av vad språkforskningen ägnar sig åt eller med en utredning av vad språk egentligen är. Här har sätten växlat men tyngden har legat vid det senare. Exempel från forskningen har lyfts in för att illustrera teorin.

Samma fråga besvaras av den moderna lingvistiken med en häftig manöver. Inte är bara utredningarna korta och sällsynta. Effekten är också våldsam. I ett slag avlägsnas alla språkliga fakta som faller utanför ett välavgränsat och regelbundet system. Språk reduceras till grammatik. Naturligtvis kan man ägna sig åt grammatik utan att göra sig skyldig till denna ontologiska reduktionism. Men när man hävdar grammatikens autonomi, då är manövern ett alexanderhugg. Identiteten upphöjs till väsen utan att dess relation till variationen är klarlagd.

Problemet med den moderna lingvistikens svar är alltså inte att grammatiken skulle sakna ett faktiskt korrelat. Problemet är att forskningen blir blind för sin egen tolkningspraktik. Som mest medger den moderna lingvistiken tolkningsmomentet i den strukturerande akten. Mängden grammatiska teorier är väl nog evidens. Att det även finns en 


\section{Andreas Widoff}

tolkande, meningsgivande akt är däremot förbisett. Om denna akt alls uppfattas tas den för naturlig. Grammatikens universaliserande tolkning är dock konstlad och står i stark kontrast till vardagens partikulära tolkning. När vi ställs inför en exempelsats förstår vi den på ett radikalt annorlunda sätt än när vi stöter på samma sats i verkligt bruk. Den moderna lingvistiken har varken viljan att se eller verktygen att beskriva denna diskrepans. Språket blir därmed en beslöjad abstraktion.

Gentemot denna tankestil har jag formulerat ett bredare språkbegrepp. I Bachtins efterföljd har jag antagit yttrandet som elementär språklig enhet. Men till skillnad från Bachtin har jag undvikit att alltför mycket betona språkets oregelbundenhet. Istället har jag försökt att förena det universella med det partikulära, det identiska med det varierande. Härigenom har jag formulerat en kontinuerlig språkmodell, där språket föreställs som en helhet från konkret till abstrakt betydelse. Till denna modell har jag slutligen fogat en tolkningstypologi som grundas på en hermeneutisk förståelse av språket. Typologin låter oss klassificera språkvetenskapens discipliner samtidigt som den är en beskrivning av språkets betydelsestruktur. Ingen tolkningstyp i sig kan fokusera en språkets kärna. Men tillsammans låter de oss överblicka språkets fulla vidd.

Undersökningen kan sammanfattas i tre principer. En konkret princip som säger att språket antar en unik betydelse för varje situation: språk betyder såsom det används. En dialektisk princip som säger att vi måste beakta språkets mångsidighet: språk är såväl identitet som variation. Och en hermeneutisk princip som säger att föremålet för förståelsen inte är autonomt i relation till förståelsen: språk betyder såsom det förstås. Dessa utsagor bildar grunden till en dialogisk språkvetenskap.

\section{Noter}

1 Härvid förutsätter jag att Bachtin-Volosjinov och Heidegger-Gadamer har en hel del beröringspunkter. Här kommer jag dock inte att ägna dem någon idéhistorisk jämförelse, som i en mer kvalificerad mening skulle bringa dessa i dagen. Detta skulle föra mig alltför långt ifrån mitt egentliga ärende. Någon grundlig sådan jämförelse har jag inte heller kunnat finna. Se dock Sidorkin (1999:24ff) som diskuterar Bachtin och Gadamer i ett kortare avsnitt och Bernard-Donals (1994) om Bachtins relation till fenomenologi och marxism.

2 Man bör veta att Saussure (1970:39) insisterar på att la langue inte är en abstraktion. Språkliga tecken är, säger han, en realitet inneboende i hjärnan, som dessutom, från den yttre sidan av saken, är möjliga att ta på. 


\section{Lingvistik, dialogism, hermeneutik}

Saussures begrepp om det konkreta sträcker sig synbarligen inte längre än till 'reell' och 'påtaglig'. En mer vetenskaplig förståelse ger också innebörder som 'partikulär' och 'sammansatt'. Detta är vad jag avser med ordet i det följande. I denna mening kan nog inte la langue vara konkret ens i Saussures ögon.

3 I både det dialogiska och hermeneutiska sammanhanget avses med värld 'världen för människan'. Det rör sig således om en specifikt humanistisk problematik, bunden till människans sätt att vara.

4 Detta är något av en förenkling, och det medger Volosjinov. Humboldt vill gärna sammanbinda "nation" och "individ", men han sår samtidigt ett subjektivistiskt frö för efterföljarna att skörda.

5 Thibault (1997) har velat nyansera den här bilden av Saussure genom att hävda att denne introducerar en metodologi mer än en ontologi. Dennes nyansering synes dock vara mer konstruktiv läsning än exeges. Det senare har inte heller varit syftet (s. xix). Jag insisterar därför på att den traditionella förståelsen av Saussure bland efterföljare och kritiker åtminstone i stora drag varit riktig. Se även Lähteenmäki (1998:56f) som ställer sig skeptisk till Thibault.

6 Jfr Bachtins (1997:233) kommentar att yttranden är sammanbundna såsom Leibniz' monader. Idén han har för ögonen är sannolikt: "Detta samband mellan alla skapade ting eller denna anpassning av alla efter envar och av envar efter alla de andra gör att varje enkel substans innehåller relationer som uttrycker alla de andra, och att den följaktligen ständigt är en levande spegel av universum" (Leibniz 1990:82 § 56).

7 Wittgenstein besvarar inte sin egen fråga. Han anmärker endast att om personen varje gång säger något nytt, så kan han inte följa en regel. Möjligen avser han med detta att framhålla en paradox. Här försöker jag istället att bejaka och fullfölja motsättningen på dialektiskt vis.

8 Jag gör ingen principiell skillnad mellan förståelse och tolkning. Men jag föredrar den senare termen när det handlar om en utveckling av förståelsen eller om en ansträngning för att uppnå förståelse.

9 Termen tillvaro ska förstås efter Heidegger (1992). Tillvaron är det varande som förstår sig själv och sitt vara och därför har möjlighet att ställa frågan om varat. Något förenklat är det ett begreppsligt förvärldsligande av det självmedvetnas medvetande.

10 Detta avviker en smula från Bachtins språkbruk. Han talar egentligen lite om just "tolkning" och säger snarare "handling" eller "yttrande". Tolkningen tycks dock alltid vara implicit i hans resonemang.

11 Heideggers argumentation - där han räknar med både saker och språk - visar att han inte hänger sig åt språklig solipsism. Detta är annars en förekommande tolkning av den konstitutiva språkuppfattningen. Se Anton (1999) för en utförlig diskussion. 


\section{Andreas Widoff}

12 Naturligtvis genom att med en modifikation inkludera, inte genom att förneka menandet, referensen, differensen, sanningsvillkoren, språkhandlingen etc.

13 Detta är förvisso ett vilseledande uttryck, som följer på föreställningen om direkta och indirekta betydelser. Fastän vi alltid läser på själva raderna alltid läser orden som verkligen står där - föreslår uttrycket att vi ibland inte gör så, som om betydelserna egentligen funnes någon annanstans än $\mathrm{i}$ språket.

14 Vad en sådan tolkning riktar sig mot är givetvis inga äkta universalier, varken i meningen ideala begrepp eller egenskaper gemensamma för alla mänskliga språk. Den avgränsar snarare den yttersta betydelsemässiga konstans, som kan fastställas för ett språkligt uttryck i ett visst språk. Jag finner mig nödgad att ta till termen "universell" för att skilja ut denna abstraktionsnivå.

15 Jfr Searles (1969) institutional facts som kontrasterar mot Anscombes (1958) brute facts.

16 Den universella betydelsens problem är genomgripande och kan i sin helhet inte behandlas här. Vi kan endast notera ytterligare några principiella linjer i frågan: en från min synpunkt överdrivet stark tro på permanens (Searle 1977), kärnan som minimerad till ett spår (Derrida 1988 influerad av Saussure), kärnan som negativt definierat värde (Saussure 1970 i en vanlig men något förvanskad läsning) eller kärnan helt och hållet avvisad till förmån för familjelikhet (Wittgenstein 1992).

17 Att grammatiken skulle vara entalig är förstås en förenkling. Man får förstå detta jämförelsevis.

18 Som språkforskare förminskar vi det lätt till ett gissel, såsom när informanter inte bedömer våra exempelmeningar som tänkt (med avseende på grammatikalitet eller dylikt), utan istället förstår dem på ett alldagligt och partikulärt vis.

19 Denna definition av yttrandet överensstämmer i mycket grova drag med Welleks (1936 och 1956 tillsammans med Warren) och Ingardens (1976) studier av det litterära verkets väsen: det är historiskt och tidsligt förankrat. Jag har dock fördjupat innebörden av denna förankring med språkinstanserna och det partikulära tolkningsfältet som vägledande begrepp.

Vidare ska noteras att jag endast har berört frågan om alla yttrandens gemensamma konstitution: frågan om yttrandets beskaffenhet överhuvud. Jag har inte diskuterat frågan om yttrandets identitet genom de skilda tolkningarna: frågan om yttrandets singulära väsen. Detta är ett problem för den identitetssökande tolkningslinjen som inte utreds här. Jag har inte heller diskuterat frågan om det mångfaldigade yttrandets identitet genom de skilda exemplaren (se Wendt 2006 och 2009 och Du Rietz 2008 härom; 
jfr även Pettersson 1981). Alla dessa frågor brukar behandlas under beteckningar som textbegreppet och verkbegreppet. I sista hand faller de dock tillbaka på frågan om yttrandets beskaffenhet överhuvud. Även om Wendt och Du Rietz ägnar mycket möda åt tekniska definitionsfrågor, rör deras problem ytterst vilken variation det mångfaldigade yttrandets identitet tillåter på uttrycksplanet. Det är tveksamt om frågan kan besvaras i allmänhet. I det enskilda fallet är det dock klart att den inte kan besvaras utan en tolkning av föreliggande versioner som klargör vad som är centralt och vad som är perifert. Vi återfaller alltså på frågan om yttrandets singulära väsen. När vi sedan försöker besvara denna fråga måste vi ha svar på vad som är tolkningarnas föremål - var identiteten måste befinna sig. Detta har jag besvarat med begreppet språkinstanser. Utan detta svar hänger de andra frågorna i luften.

\section{Litteratur}

Althusser, Louis 1965. För Marx. Staffanstorp: Bo Cavefors förlag.

Anscombe, G.E.M. 1958. On brute facts. Analysis 18,3:69-72.

Anton, Corey 1999. Beyond the constitutive-representational dichotomy. The phenomenological notion of intentionality. Communication theory 9,1:2657.

Austin, John L. 1962. How to do things with words. The William James Lectures delivered at Harvard University in 1955. New York: Oxford University Press.

Bakhtin, Mikhail 1986. Speech genres and other late essays. (University of Texas Press Slavic series 8.) Austin: University of Texas Press.

Bachtin, Michail [1929/1963] 1991. Dostojevskijs poetik. Gråbo: Anthropos.

Bachtin, Michail 1997. Frågan om talgenrer. I: Eva Hættner Aurelius \& Thomas Götselius (red.). Genreteori. Lund: Studentlitteratur:203-239.

Bakhtin, Mikhail [1919-21] 1993. Toward a philosophy of the act. Austin: University of Texas Press.

Bachtin, Michail [1935] 2003. Ordet i romanen. (Moderne tænkere.) Köpenhamn: Gyldendal.

Bernard-Donals, Michael F. 1994. Mikhail Bakhtin. Between phenomenology and Marxism. Cambridge: Cambridge University Press.

Carroll, Lewis 1992. Alice in Wonderland. Authoritative texts of Alice's adventures in Wonderland. Through the looking-glass. The hunting of the snark. Backgrounds. Essays in criticism (2. ed.). New York: Norton.

Chomsky, Noam 1965. Aspects of the theory of syntax. Cambridge: M.I.T. Press.

Derrida, Jacques [1972] 1988. Signaturen Event Context. I: Limited Inc.:1-23. Evanston: Northwestern University Press.

Du Ritz, Rolf. E. (2008). Textbegreppet än en gång. Arkiv för nordisk filologi 123:157-167. 
Fairclough, Norman 1992. Discourse and Social Change. Cambridge: Polity Press.

Fairclough, Norman 2010. Critical discourse analysis in researching language in the new capitalism: overdetermination, transdisciplinarity and textual analysis. I: Critical discourse analysis. The critical study of language (2. ed.):281-300. Harlow: Longman.

Fleck, Ludwik [1935] 1997. Uppkomsten och utvecklingen av ett vetenskapligt faktum. Inledning till läran om tankestil och tankekollektiv. Stockholm: Symposium.

Foucault, Michel [1969] 2002. Vetandets arkeologi. Lund: Arkiv förlag.

Freud, Sigmund [1899-1930] 2002. Drömtydning. Stockholm: Natur och Kultur.

Gadamer, Hans-Georg 1984. The hermeneutics of suspicion. Man and world 17:313-323.

Gadamer, Hans-Georg [1960] 1986a. Warheit und Methode. Grunzüge eider philosophischen Hermeneutik. (Gesammelte Werke. Bd 1. Hermeneutik I. Wahrheit und Methode.) Tübingen: Mohr.

Gadamer, Hans-Georg [1959] 1986b. Vom Zirkel des Verstehens. I: Gesammelte Werke. Bd 2. Hermeneutik II. Wahrheit und Methode. Tübingen: Mohr:57-65.

Gadamer, Hans-Georg [1965] 1986c. Vorwort zur 2. Auflage. I: Gesammelte Werke. Bd 2. Hermeneutik II. Wahrheit und Methode. Tübingen: Mohr:437-448.

Gadamer, Hans-Georg [1975] 1995. Subjektivität und Intersubjektivität, Subjekt und Person. I: Gesammelte Werke. Bd 10. Hermeneutik im Rückblick. Tübingen: Mohr:87-99.

Goodwin, Charles 1984. Notes on story structure and the organization of participation. I: J. Mawwell Atkinson \& John Heritage (red). Structures of social action. Studies in conversation analysis. Cambridge: Cambridge University Press:225-246.

Gregersen, Frans 2006. Strukturalismen i vore hjerter. Eller: i virkeligheden er vi jo alle en slags strukturalister. Nydanske sprogstudier 34-35 ("Sprogvidenskabelige forskningstraditioner"):11-52.

Gustafsson, Anna 2009. Pamfletter! En diskursiv praktik och dess strategier $i$ tidig svensk politisk offentlighet. (Lundastudier i nordisk språkvetenskap A 66.) Lund: Lunds universitet.

Halliday, M.A.K. Language as social semiotic. The social interpretation of language and meaning. Baltimore: University Park Press.

Halliday, M.A.K. \& Christian Matthiessen 2004. An introduction to functional grammar. 3. ed. London: Arnold.

Have, Paul ten 2007. Doing conversation analysis. (2 ed.) London: SAGE.

Heidegger, Martin [1978] 1984. The metaphysical foundations of logic. Bloomington: Indiana University Press.

Heidegger, Martin [1936] 1990. Konstverkets ursprung. Göteborg: Daidalos. 
Heidegger, Martin [1927] 1993. Varat och tiden. Del 1. Göteborg: Daidalos. Henriksen, Carol, Even Hovdhaugen, Fred Karlsson \& Bengt Sigurd (red.) 1996. Studies in the development of linguistics in Denmark, Finland, Iceland, Norway and Sweden. Papers from the Conference on the History of Linguistics in the Nordic Countries, Oslo, 20-22 November, 1994. Oslo: Novus.

Hodge, Robert \& Gunther Kress 1988. Social semiotics. Cambridge: Polity Press.

Holquist, Michael 1990. Dialogism. Bakhtin and his world. London: Routledge.

Hovdhaugen, Even, Fred Karlsson, Carol Henriksen \& Bengt Sigurd 2000. The history of linguistics in the Nordic countries. Helsinki: Societas Scientiarum Fennica.

Humboldt, Wilhelm von [1836]. Über die Verschiedenheit des menschlichen Sprachbaues und ihren Einfluß auf die geistige Entwicklung des Menschengeschlects. Über die Sprache.

Husserl, Edmund [1900/1913] 2000. Logiska undersökningar. Bd 2. Undersökningar kring kunskapens fenomenologi och teori I-IV. Stockholm: Thales.

Husserl, Edmund [1913] 2004. Idéer till en ren fenomenologi och fenomenologisk filosofi. Stockholm: Thales.

Ingarden, Roman [1936/1968] 1973. The cognition of the literary work of art. Evanston: Nortwestern University Press.

Ingarden, Roman [1930] 1976. Det litterära konstverket. Lund: Bo Cavefors bokförlag.

Jakobson, Roman 1960. Linguistics and poetics. I: Thomas A. Sebeok (ed). Style in language. Cambridge: M.I.T:350-377.

Kosík, Karel [1963] 1979. Det konkretas dialektik. En studie i människans och världens problematik. Göteborg: Röda Bokförlaget.

Ledin, Per 1999. Texter och textslag - en teoretisk diskussion. (Svensk sakprosa 27). Lund.

Leibniz, G.W. [1714] 1990. Monadologin. I: Valda skrifter. Stockholm: Natur och kultur.

Lindström, Jan 2008. Tur och ordning. Introduktion till svensk samtalsgrammatik. Stockholm: Norstedts.

Linell, Per 1998. Approaching dialogue. Talk, interaction and context in dialogical perspectives. (Impact: Studies in language and society 3.) Amsterdam: John Benjamins.

Linell, Per 2002. What is dialogism? Aspects and elements of a dialogical approach to language, communication and cognition. (Arbetsrapporter från Tema K.) Linköping: Tema Kommunikation.

Lähteenmäki, Mika 1998. On Dynamics and Stability. Saussure, Voloshinov, and Bakhtin. I: Mika Lähteenmäki \& Hannele Dufva (ed). Dialogues on Bakhtin. Interdisciplinary Readings:52-71. 
Martin, J.R. \& David Rose 2008. Genre relations. Mapping culture. London: Equinox.

Marx, Karl \& Friedrich Engels [1846] 1958. Die deutsche Ideologie. (MarxEngels-Werke 3.) Berlin: Dietz Verlag.

Marx, Karl [1857-8] 1971. Grunddragen i kritiken av den politiska ekonomin. I urval. Lund: Zenit.

Morson, Gary Saul \& Caryl Emerson 1990. Mikhail Bakhtin. Creation of a prosaics. Stanford: Stanford University Press.

Ogden, C.K. \& I.A. Richards [1923] 1989. The meaning of meaning. A study of the influence of language upon thought and of the science of symbolism. San Diego: Harcourt Brace Jovanovich.

Pettersson, Anders 1981. Verkbegreppet. En litteraturteoretisk undersökning. Oslo: Novus forlag.

Ricœur, Paul 1988. Hermeneutik och ideologikritik. I: Från text till handling. En antologi om hermeneutik. Stockholm: Symposion:99-166.

Saussure, Ferdinand de [1916] 1970. Kurs i allmän lingvistik. Lund: Bo Cavefors bokförlag.

Schlegel, Friedrich [1797] 1981. Zur Philologie. II. I: Kritische FriedrichSchlegel-Ausgabe. Bd 16. Paderborn: Schöningh:59-81.

Searle, John. R. 1969. Speech acts. An essay in the philosophy of language. Cambridge: Cambridge University Press.

Searle, John 1977. Reiterating the Differences. A Reply to Derrida. Glyph 1:198-208.

Shannon, Claude E. \& Warren Weaver [1949] 1998. The mathematical theory of communication. Urbana: University of Illinois Press.

Sidorkin, Alexander M. 1999. Beyond discourse. Education, the self, and dialogue. Albany: State University of New York Press.

Sonesson, Göran 2002. The varieties of interpretation. A view from semiotics. Galáxia 4:67-99.

Svensson, Jan 1988. Nordistikens kunskapsintressen. I: Nordistiken som vetenskap. Artiklar om ämnets historia, teorier och metoder. Lund: Studentlitteratur.

Svensson, Jan 2010. Språket som hydra - några tankar om språkvetenskapliga analysperspektiv. Skandinaviske sprogstudier 1:40-66.

Therkelsen, Rita; Nina Møller Andersen \& Henning Nølke 2007. Sproglig polyfoni. Tekster om Bachtin og ScaPoLine. Århus: Aarhus universitetsforlag.

Thibault, Paul J. 1997. Re-reading Saussure. The dynamics of signs in social life. London: Routledge.

van Dijk, Teun A. 1972. Some aspects of text grammars. A study in theoretical linguistics and poetics. The Hague: Moton.

Vološinov, V.N. [1929] 1973. Marxism and the philosophy of language. (Studies in language 1.) New York: Seminar Press. 
Voloshinov, V.N. [1928] 1983a. The latest trends in linguistic thought in the West. I: Ann Shukman (red). Bakhtin school papers:31-49.

Voloshinov, V.N. [1930] 1983b. The word and its social function. I: Ann Shukman (red). Bakhtin school papers:139-152.

Wellek, René 1936. The theory of literary history. I: Études dédiées au quatrième congrès de linguistes. (Travaux du Cercle linguistique de Prague 6.) Prague.:173-191.

Wellek, René \& Austin Warren 1956. Theory of literature (2. ed). New York: Harcourt, Brace and Company.

Wendt, Bo-A. 2006. En text är en text är en text? Om en terminologisk tredelning av textbegreppet. Arkiv för nordisk filologi 121:253-274.

Wendt, Bo-A. 2009. Text som mängd eller helhet - och i verkligheten. Om en språkvetares textbegrepp. Text. Svensk tidskrift för bibliografi 7,3:140159.

Wittgenstein, Ludwig [1953] 1992. Filosofiska undersökningar. Stockholm: Thales.

Andreas Widoff

Nordiska språk

Språk- och litteraturcentrum

Lunds universitet

Andreas.Widoff@nordlund.lu.se 